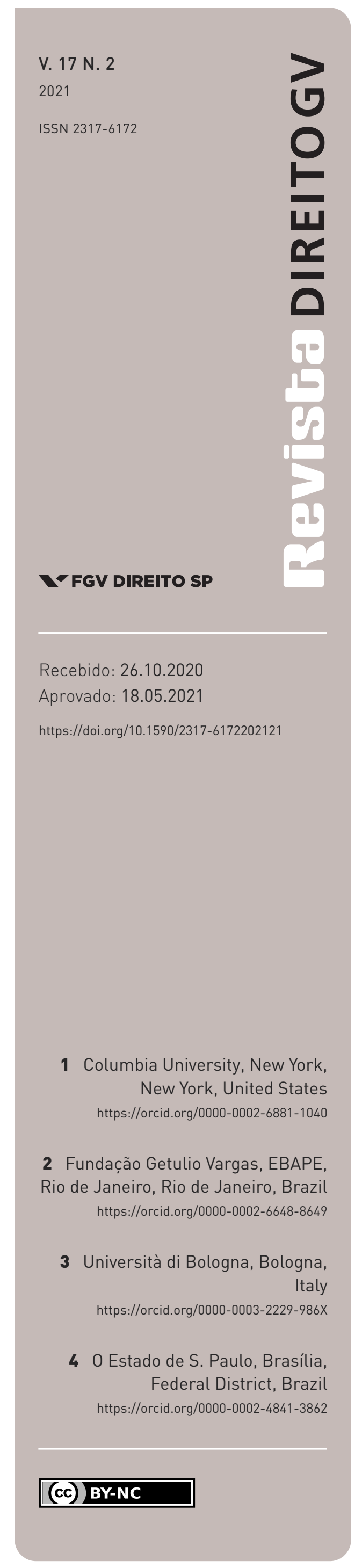

\section{President Bolsonaro's Promises and Actions on Corruption Control}

\author{
PROMESSAS E AÇÕES DO PRESIDENTE BOLSONARO SOBRE CORRUPÇÃO
}

Paul Lagunes', Gregory Michener ${ }^{2}$, Fernanda Odilla ${ }^{3}$ and Breno Pires ${ }^{4}$

\begin{abstract}
Before the 2018 Brazilian presidential elections, candidate Jair Bolsonaro offered a bold message on corruption control. Among his promises, Bolsonaro vowed to promote government transparency, dismiss any member of his team accused of corruption, and defend the country's institutions of accountability. Bolsonaro also offered to support a once-popular legislative reform proposal known as the Ten Measures Against Corruption. However, it is worth cautioning that anticorruption as a rhetorical device has been a near-permanent feature of the Brazilian political landscape. In this article, we seek to compare Bolsonaro's campaign promises with his early actions as president. The evidence shows that, months after the 2018 elections, President Bolsonaro has failed the anticorruption mandate on which he was elected.
\end{abstract}

\section{Keywords}

Corruption; Brazil; mandate; accountability; democracy.

\section{Resumo}

Antes das eleições presidenciais de 2018 no Brasil, o candidato Jair Bolsonaro apresentou um discurso arrojado para o combate à corrupção. Entre as promessas que fez, comprometeu-se a promover a transparência no governo, demitir qualquer integrante de sua equipe acusado de corrupção e defender as instituições de controle no país. Também ofereceu apoio ao então popular projeto de lei conhecido como Dez Medidas Contra a Corrupção. No entanto, é importante alertar que o discurso anticorrupção, como um artifício retórico, é uma característica quase permanente do cenário político brasileiro há anos. Neste artigo, comparamos as promessas de campanha de Bolsonaro com suas ações enquanto presidente. Os dados indicam que, meses após as eleições de 2018, o presidente Bolsonaro falhou na promessa de um mandato anticorrupção para o qual foi eleito.

\section{Palavras-chave}

Corrupção; Brasil; mandato; accountability; democracia. 


\section{INTRODUCTION}

In 2018, before the Brazilian presidential elections, candidate Jair Bolsonaro celebrated the fact that he was one of a few politicians not to have received irregular funding from Petrobras (LUPA, 2018). ${ }^{1}$ This was of consequence considering that the massive corruption scandal known as Lava Jato had begun at the Brazilian state-owned oil company (DAVIS, 2019, p. 163). In response to the corruption revelations, high-level government officials were convicted, powerful firms were forced to pay restitution, and the Brazilian system of accountability appeared to reach a new level of efficacy (ARANHA, 2020, p. 94-95 and 99-101; GANLEY and LAGUNES, 2020a, p. 227-228). ${ }^{2}$ Building on this momentum, candidate Bolsonaro promised citizens a different kind of government: an honest government. ${ }^{3}$

Jair Messias Bolsonaro is an army captain who, as a representative for the state of Rio de Janeiro, served for nearly thirty years in Congress (CÂMARA DOS DEPUTADOS, n.d.). He is described by critics as a right-wing populist known for making disparaging comments against women, gays, and blacks (LEAHY and SCHIPANI, 2018; SIMÕES, 2018; CHILD, 2019). In an apparent challenge to due process and human rights, Bolsonaro is on the record saying that "a good criminal is a dead criminal" (LONDOÑO and ANDREONI, 2018). Earlier in his political career, Bolsonaro even went so far as to call for authoritarian intervention in Brazil (WILSON CENTER, 2018). In a 1999 interview, he warned that if he ever became president, he would close Congress (SIMÕES, 2018). "I would stage a military coup on the first day," he said (HELAL FILHO, 2019). ${ }^{4}$ "Through the vote," he added, "you will not change anything in this country" (HELAL FILHO, 2019). ${ }^{5}$

But even as Bolsonaro has, at times, appeared unsympathetic to democracy and its ways, he has advanced his political career through none other than the path made available to him by democracy. And, in his aspiration for higher office, Bolsonaro announced his bid for the presidency in July of 2018.

1 The translation of Jair Bolsonaro's statement: "My name was mentioned by Mr. Alberto Youssef [a blackmarket dealer] during his plea agreement [as] one of the three congressional members who did not receive money from Petrobras.” The original quote: “Eu fui citado pelo senhor AlbertoYoussef, por ocasião de sua delação premiada, [como] um dos três deputados que não foi pegar dinheiro na Petrobras” (LUPA, 2018).

2 For a relevant discussion of Brazil's accountability system, see: PRADO and CORNELIUS (2020).

3 As stated in candidate Jair Bolsonaro's government plan (authors' translation): "We propose a decent government [that will be] different from all that which has thrown us into an ethical, moral, and fiscal crisis. A government without quid pro quo, without spurious agreements." The original quote: "Propomos um governo decente, diferente de tudo aquilo que nos jogou em uma crise ética, moral e fiscal. Um governo sem 'toma-lá-dá-cá', sem acordos espúrios" (BOLSONARO, 2018a, p. 2).

4 The original statement: "Não há a menor dúvida, daria golpe no mesmo dia” (HELAL FILHO, 2019).

5 The original statement: "Através do voto você não vai mudar nada nesse país, nada, absolutamente nada" (HELAL FILHO, 2019). 
Throughout the campaign season (and even shortly after winning the election), Bolsonaro expressly championed the anticorruption cause (see Figure 1). In fact, he made a number of specific promises on the matter. For instance, Bolsonaro promised to promote government transparency (CAMPOS and GONÇALVES, 2019). He also promised to dismiss any member of his team accused of corruption (MONTEIRO, LINDNER and LIMA, 2018; FERNANDES, 2018; HOUS, 2018) and to defend the country's institutions of accountability (BOLSONARO, 2018a, p. 12). Regarding this last promise, Bolsonaro offered assurances that he would support the Lava Jato Task Force and its efforts to combat corruption (BOLSONARO, 2018b). Bolsonaro similarly offered to support the Lava Jato Task Force's once-popular legislative reform proposal known as the Ten Measures Against Corruption (BOLSONARO, 2018a, p. 35). ${ }^{6}$

figure 1 - Words Emphasized in Candidate Bolsonaro's Government Plan

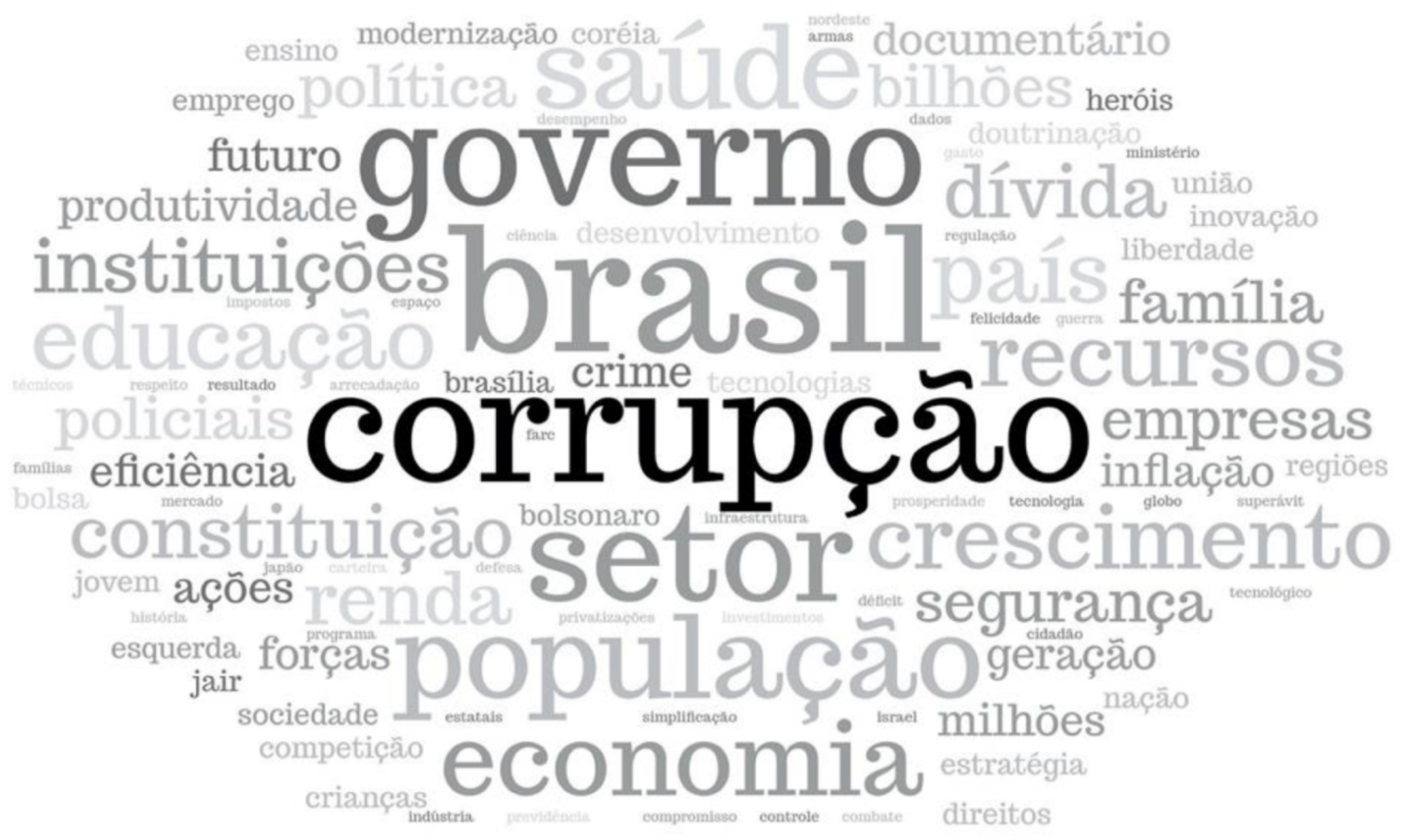

The word cloud depicts the frequency with which topics are mentioned in the body of candidate Bolsonaro's official government plan. To generate the word cloud, we removed extraneous text and eliminated all remaining non-topical words. While the average word shown in the figure appears five times, the term corrupção appears thirteen times. The word cloud illustrates the relative importance of the corruption theme to Bolsonaro's 2018 presidential campaign. Source text: BOLSONARO, Jair. O caminho da prosperidade: proposta de plano de governo. Brazil, 2018.

6 The Ten Measures (or, as it was referred to in Brazil, "Dez Medidas Contra a Corrupção") included proposals to end some of the legal privileges that make it difficult to prosecute elected officials, whileamong other things - increasing the penalties for officials convicted of corruption (CARVALHO, 2016, p. 5; BULLOCK and STEPHENSON, 2020, p. 216). 
Bolsonaro's strategy of railing against the corrupt status quo appeared to work. He won the presidency and, in his inaugural speech, called on all members of Congress to free Brazil of corruption (UOL, 2019). However, it is worth cautioning that anticorruption as a rhetorical device has been a near-permanent feature of the Brazilian political landscape (AVRITZER et al., 2008; DOS SANTOS, 2017; SADEK, 2019). The question is whether the disconnect between what politicians promise and what they actually deliver is of relevance to the health of a democracy.

In this article, we assume that political rhetoric matters and that hypocrisy-however common - is in tension with accountability. During electoral campaigns, rhetoric is the means by which candidates communicate information to voters (DOWNS, 1957), consequently shaping expectations about the future of policy (STOKES, 2001, p. 2-4). Presidential inaugural addresses are similarly important considering that they set the tone and the policy agenda for the incoming administration (RAGSDALE, 1984; CAMPBELL and JAMIESON, 2018). If officials go on to deliver on their early promises, they can be thought of as responsive to voters (O'DONNELL, 1994, p. 58). In this sense, responsiveness is achieved when "the democratic process induces the government to form and implement policies that the citizens want" (POWELL, 2004, p. 91).

With this in mind, we join those who warn about the importance of validating Jair Bolsonaro's words against his actions (ROSE-ACKERMAN and PIMENTA, 2020, p. 205). Two years after the 2018 elections, there is a growing body of evidence - summarized in the substance of this article - that President Bolsonaro has failed the anticorruption mandate that he set for himself. This is not to imply that everything about Bolsonaro's administration can be judged a disappointment. Similarly, we do not pretend that, as president, Bolsonaro can control everything relating to corruption in Brazil. ${ }^{7}$ Also, it is at least plausible that a few of the troubling trends highlighted here may be reversed before the President concludes his term. ${ }^{8}$ But whatever happens in the years ahead, this article should serve as a resource that tracks Jair Bolsonaro's original promises and early actions on the subject of corruption control.

\section{i. Political Promises, Corruption Scandals, and Institutional Development}

Jair Bolsonaro is by no means the first politician to make promises regarding corruption control. In this section, we trace Brazil's decades-long path of scandal and institutional development while also spotlighting other contemporary presidents who have made notable

7 That said, the president is a central actor with strong legislative powers in the Brazilian governing system (ABRANCHES, 1988; FIGUEIREDO and LIMONGI, 2007; MELO and PEREIRA, 2013).

8 Much of this article was drafted between the months of May and October of 2020. By the time this article is published, President Bolsonaro will have been in office for more than two years. 
promises to fight corruption. Our brief historical review places Bolsonaro's actions in broader context and introduces the institutional actors that will prove central to our analysis later, in Section 2.

\section{I. i. Institutional Development:The Federal Prosecution System}

We begin our historical review by noting that the years of military rule in Brazil — that is, the years between 1964 and 1985-were marred by scandal (GEDDES and RIBEIRO NETO, 1992 , p. 647). Table 1 lists the most prominent corruption scandals that occurred during the administrations of generals Emílio Garrastazu Médici (1969-1974), Ernesto Geisel (19741979), and João Baptista Figueiredo (1979-1985).

table 1 - Presidential Promises to Fight Corruption \& Corruption Scandals (1964-1992)

\begin{tabular}{|c|c|c|c|c|}
\hline PRESIDENT & YEAR & $\begin{array}{l}\text { PROMISED TO FIGHT } \\
\text { CORRUPTION WHEN } \\
\text { TAKING OFFICE }^{1}\end{array}$ & $\begin{array}{l}\text { FEATURED AS } \\
\text { CORRUPTION FIGHTER }\end{array}$ & $\begin{array}{l}\text { CORRUPTION SCANDALS } \\
\text { OF NOTE }{ }^{3}\end{array}$ \\
\hline $\begin{array}{l}\text { HUMBERTO DE ALENCAR } \\
\text { CASTELO BRANCO }\end{array}$ & $1964-1967$ & YES & YES & \\
\hline ARTUR DA COSTA E SILVA & 1967-1969 & NO MENTION & NO & \\
\hline GOVERNING JUNTA & 1969 & MISSING DATA ${ }^{\theta}$ & NO & \\
\hline $\begin{array}{l}\text { EMÍLIO GARRASTAZU } \\
\text { MÉDICI }\end{array}$ & 1969-1974 & NO MENTION & NO & $\begin{array}{l}\text { GOVERNADORES BIÔNICOS (BIONIC } \\
\text { GOVERNORS); FLEURY (1973). }\end{array}$ \\
\hline ERNESTO GEISEL & 1974-1979 & NO MENTION & YES & $\begin{array}{l}\text { DELFIM NETO/CAMARGO CORRÊA } \\
\text { (1974); PERKS FOR MINISTERS AND } \\
\text { HIGH-LEVEL CIVIL SERVANTS (1976); } \\
\text { GENERAL ELECTRIC (1976). }\end{array}$ \\
\hline $\begin{array}{l}\text { JOÃO BAPTISTA } \\
\text { FIGUEIREDO }\end{array}$ & 1979-1985 & YES & YES & $\begin{array}{l}\text { LUTAFLLA CASE (1979); NEWTON } \\
\text { CRUZ/CAPEMI (1982); GRUPO DELFIN } \\
\text { (1982); COROA BRASTEL (1985). }\end{array}$ \\
\hline JOSÉ SARNEY & $1985-1990$ & NO MENTION & & $\begin{array}{l}\text { FERROVIA NORTE-SUL (NORTHERN- } \\
\text { SOUTHERN RAILROAD) (1987); CPI DA } \\
\text { CORRUPÇÃO (1988); CASO BR (1988). }\end{array}$ \\
\hline $\begin{array}{l}\text { FERNANDO COLLOR } \\
\text { DE MELLO }\end{array}$ & 1990-1992 & YES & YES & $\begin{array}{l}\text { JORGINA DE FREITAS (1991); ROSANE } \\
\text { COLLOR (1991); PC/COLLORGATE. }\end{array}$ \\
\hline
\end{tabular}

(it continues) 
${ }^{\theta}$ THE LABEL “MISSING DATA" INDICATES THAT THE PRESIDENT'S INAUGURAL SPEECH IS EITHER NOT AVAILABLE OR WAS NOT FOUND.

1 SOURCES: BIBLIOTECA DA PRESIDÊNCIA DA REPÚBLICA (N.D.) AND BONFIM (2008).

2 SOURCE: THE NEW YORK TIMES'S TIMEMACHINE (N.D.).

3 AN EMPTY CELL INDICATES THAT NO MAJOR SCANDAL WAS IDENTIFIED DURING THE TIME PERIOD OF INTEREST. ALSO, MOST OF THE INFORMATION CONTAINED UNDER THIS COLUMN WAS OBTAINED FROM FREIRE (2015). ADDITIONAL SOURCES INCLUDE: FREITAS (1987); GONDIM (1997); WAISBORD (2000); TAYLOR AND BURANELLI (2007); POWER AND TAYLOR (2011); TAVARES (2015).

Source: Authors.

After reestablishment of civilian rule through enactment of the Constitution of 1988, Brazil laid the foundations for the country's present-day system of accountability (POWER and TAYLOR, 2011; CARSON and PRADO, 2014). This critical step in institutional development is best exemplified by changes to the Federal Prosecution System (in Portuguese, Ministério Público da União or MPU). ${ }^{9}$ Reforms enacted a few years before had given the MPU greater autonomy and power (ARANTES 2002; KERCHE, 2008; PRAÇA andTAYLOR, 2014), but it is the 1988 Constitution that actually granted the MPU much of the independence that it enjoys today (ARANTES, 2004; ARANHA, 2018). However, this is not to suggest that the MPU is completely immune to external influence.

The manner by which the MPU's leadership is selected gives members of the political class an opportunity to shape the Federal Prosecution System. The head of the MPU-that is, the Chief General Prosecutor (Procurador-Geral da República) — is the person responsible for both bringing corruption charges against top-level politicians and overseeing the Federal Prosecution Service, or, as it is known in Portuguese, Ministério Público Federal (FALCÃO et al., 2017; ARANTES, 2019). Candidates to this position are first nominated by the president and then confirmed by the Senate (ABREU, 2010). As we illustrate later, it is through this selection process that congressional members and cabinet ministers have a hand in the fate of anticorruption efforts in the country.

\section{i. 2. Institutional Development: The Federal Prosecution Service}

The importance of the Ministério Público Federal — or MPF, for short — can hardly be overstated. Even accounting for the aforementioned risk of political interference, officials in

9 The MPU was created in 1951 and is headed by the Chief General Prosecutor. There are a few different agencies under the MPU's governance structure, including the Federal Prosecution Service (Ministério Público Federal, MPF), the Labor Prosecution Service (Ministério Público do Trabalho, MPT), and the Military Prosecution Service (Ministério Público Militar) (BRAZIL, 1993; ABREU, 2010). 
Brazil have learned that the MPF is an institution to be reckoned with. Since democracy was restored, prosecutors working for the MPF have been increasingly active in exposing corruption (TAYLOR and BURANELLI, 2007). In fact, the MPF stands out as the agency that led the charge during Operação Lava Jato.

And it is because of their work on Lava Jato that members of the MPF have been the object of intense controversy (GANLEY and LAGUNES, 2020b, p. 186). On the one hand, some charge those involved in the Lava Jato Task Force with committing rights violations, showing excessive dependence on evidence drawn from plea bargains, and undermining Brazilian democracy by going after elected government officials, especially from left-leaning parties (LAGUNES, 2020, p. 113). On the other hand, the Lava Jato Task Force managed to win a high number of convictions and prison sentences totaling more than 2,000 years (LAGUNES, 2020, p. 113). Thus, in one sense, Lava Jato is an entirely unique event in a national setting where corrupt elites have historically evaded conviction (TAYLOR and BURANELLI, 2007). In another sense, Lava Jato can be thought of as a recent link in the long chain of corruption scandals affecting Brazil even after democracy was reestablished in $1988 .^{10}$

\section{I.3. Corruption Scandals: From Sarney to Collor}

It is in 1988 that a parliamentary inquiry committee (in Portuguese, Comissão Parlamentar de Inquérito or $\mathrm{CPI}$ ) was created in Congress to investigate corruption in President Jose Sarney's administration (FOLHA DE S.PAULO, 1994b). While the committee recommended impeaching Sarney, the Lower Chamber voted against the measure (FIORI, 2006). ${ }^{11}$ Still, the multiple scandals witnessed during the Sarney administration (see Table 1) are seemingly what led a number of presidential candidates in the 1989 election to promise to fight corruption. Among the various candidates, Fernando Collor de Mello was nicknamed the "hunter of maharajahs" due to his penchant for attacking the high salaries and perks of public officials (SCHNEIDER, 1991).

We fully acknowledge that witnessing scandals during a given presidential administration is not necessarily the result of broken promises or lack of political responsiveness. In fact, it could reflect the opposite. More accountable or responsive administrations might be more inclined to spotlight and confront corruption, thus increasing the number of scandals observed over a given time period. Following this line of thinking, readers should view the lack of corruption scandals during the 1964-1969 period with skepticism (see Table 1). Is it that corruption was actually under control during this period of military rule, or is it that the lack of freedom and democracy in Brazil before 1988 made it easier to hide corruption allegations? In our opinion, the latter seems more likely.

11 The year before, the same newspaper had revealed allegations of irregularities in the public bidding for the construction of a railroad, leading to another congressional inquiry (CPI Ferrovia Norte e Sul) and the cancellation of the bidding (FREITAS, 1987; WAISBORD, 2000; POWER and TAYLOR, 2011, p. 2). 
Upon winning the presidential election, Collor used his inaugural speech to reaffirm his commitment to anticorruption (see Table 1). After some time in office, however, scandals involving his administration began to accumulate (WEYLAND, 1993). Collor ultimately resigned after a failed attempt to avoid impeachment (FIGUEIREDO, 2010). ${ }^{12}$

\section{I.4. Corruption Scandal: The Franco Administration}

When Collor left the presidency, he was replaced by Vice President Itamar Franco (19921995) whose administration soon faced corruption scandals of its own (see Table 2). For instance, the CPI dos Anões do Orçamento (in English, "Budget Dwarfs") investigated the diversion of public funds to ghost firms controlled by members of the congressional budget committee, most of whom were physically short and part of the so-called baixo clero or lower clergy (FOLHA DE S.PAULO, 1994a; FILGUEIRAS and VALE, 2002; PRAÇA, 2011; MORENO, 2015; MATAIS et al., 2016). The committee's final report recommended that eighteen of the thirty-seven parliamentarians under investigation be removed, though only six of them actually lost their mandate (FIORI, 2006). It is worth noting that, during the congressional inquiry, three governors and seven current or former cabinet ministers were accused of participating in the scheme to benefit organizations and firms, including Odebrecht (MURELLO, 1993; GASPAR, 2020).

table 2 - Presidential Promises to Fight Corruption and Corruption Scandals (1992-2018)

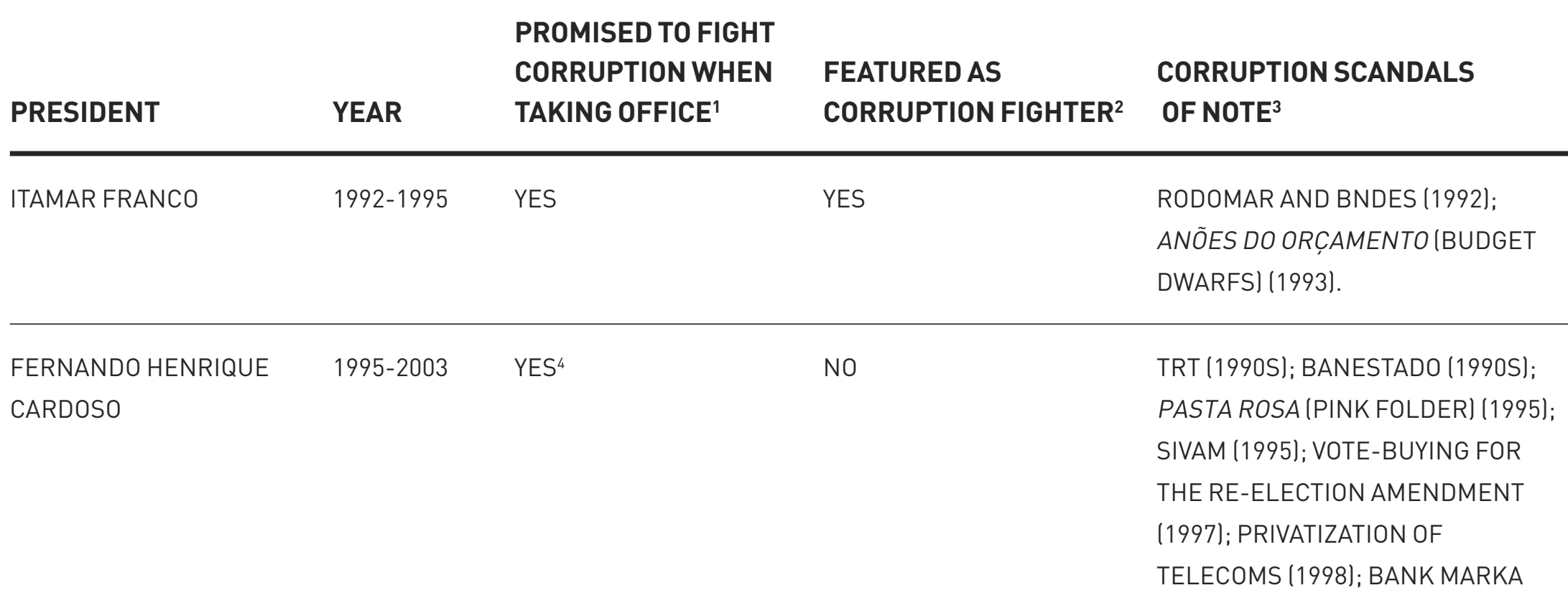

(it continues) Though President Collor was cleared of corruption charges by the Supreme Court (AURÉLIO, 2010; MOTTA,
2014), years later, while a sitting senator, he was among the politicians implicated in Lava Jato (AMORIM, 2017). 


\begin{tabular}{|c|c|c|c|c|}
\hline & & & & $\begin{array}{l}\text { AND FONTECINDAM (1999); } \\
\text { SUDAM/SUDENE (2000). }\end{array}$ \\
\hline LUIZ INÁCIO LULA DA SILVA & $2003-2011$ & $\mathrm{YES}^{4}$ & YES & $\begin{array}{l}\text { OPERATION ANACONDA (2003); } \\
\text { WALDOMIRO DINIZ (2004); MÁFIA } \\
\text { DOS VAMPIROS (VAMPIRE MAFIA) } \\
\text { (2004); MENSALÃO (2005); } \\
\text { SANGUESSUGA (2006); PALOCCI } \\
\text { (2006); BOI BARRICA/FAKTOR (2006); } \\
\text { DOSSIÊ DOS ALOPRADOS (MADMEN } \\
\text { DOSSIER, 2006); OPERATION } \\
\text { NAVALHA (2007); MENSALÃO } \\
\text { TUCANO (2007); OPERATION } \\
\text { HURRICANE (2007); SATIAGRAHA } \\
\text { (2008); CARTÕES CORPORATIVOS } \\
\text { (CORPORATIVE CARDS) (2008); } \\
\text { MENSALÃO DO DEM (2009); CASTELO } \\
\text { DEAREIA (SAND CASTLE) (2009); } \\
\text { SENATE'S SECRET ACTS (2009); } \\
\text { ERENICE CASE (2010). }\end{array}$ \\
\hline DILMA ROUSSEFF & $2011-2016$ & YES & NO & $\begin{array}{l}\text { PALOCCI (2011); CONAB (2011); } \\
\text { MINISTRY OF LABOR AND NGOS } \\
\text { (2011); SEGUNDO TEMPO (2011); } \\
\text { MÁFIA DOS TRANSPORTES } \\
\text { (TRANSPORTATION MAFIA) (2011); } \\
\text { CACHOEIRA/MONTE CARLO (2012); } \\
\text { LAVA JATO (CAR WASH) (2014). }\end{array}$ \\
\hline MICHEL TEMER & $2016-2018$ & NO MENTION & NO & $\begin{array}{l}\text { GREENFIELD (2016); JBS (2017); } \\
\text { CANDIDATURAS LARANJAS (2018); } \\
\text { RACHADINHAS (2018). }\end{array}$ \\
\hline
\end{tabular}

${ }^{\theta}$ THE LABEL “MISSING DATA” INDICATES THAT THE PRESIDENT'S INAUGURAL SPEECH IS EITHER NOT AVAILABLE OR WAS NOT FOUND.

1 SOURCES: BIBLIOTECA DA PRESIDÊNCIA DA REPÚBLICA (N.D.) AND BONFIM (2008).

2 SOURCE: THE NEW YORK TIMES'S TIMEMACHINE (N.D.).

3 SCANDALS IDENTIFIED DURING THE TIME PERIOD OF INTEREST. SOURCES INCLUDE: FOLHA (2003); FOLHA (2004); FOLHA (2006); TAYLOR AND BURANELLI (2007); MPF (2008); MPF (2010); MARQUES (2011); POWER AND TAYLOR (2011); VASCONCELOS (2013); CARSON AND PRADO (2014); BASILIO (2015); UOL (2015); CHEMIM (2017); VALENTE AND IGLESIAS (2017); BARBIÉRI (2018); CAMARGOS (2019); SHALDERS (2019); GOMES (2020); AND SENRA (2020).

4 PROMISES TO FIGHT CORRUPTION MADE ONLY IN THE FIRST TERM.

Source: Authors.

I.5. Institutional Development: The Federal Revenue Service, the Council for Control OF FinANCIAL ACTIVITIES, ANDTHE INSPECTOR GENERAL

Crucially, the Franco administration is not remembered solely for the scandals that occurred during its watch. There were several areas that witnessed notable progress. For example, the 
Federal Revenue Service (in Portuguese, Receita Federal) was granted new resources and attributions which allowed it to conduct a more effective oversight of financial transactions (POWER and TAYLOR, 2011, p. 267; PRAÇA and TAYLOR, 2014, p. 34).

Years later, during the presidency of Fernando Henrique Cardoso (1995-2002), antimoney laundering efforts were further reinforced with new legislation. The Cardoso administration also created key institutions that come up again later in this article: the Council for Control of Financial Activities (Conselho de Controle de Atividades Financeiras or COAF) and the National Disciplinary Office (Corregedoria-Geral da União or CGU). The former is responsible for countering money laundering and terrorism financing (PRAÇA and TAYLOR, 2014, p. 34; ARANHA, 2020, p. 99-100). The latter is responsible for investigating and punishing corruption among civil servants (FLEISHER, 2002; ODILLA, 2020).

\section{i.6. Corruption Scandals: The Cardoso Administration}

Unfortunately, the progress made on corruption control during the Cardoso administration is tarnished by the corruption scandals witnessed during that same period. Among these scandals was one involving allegations of congressional vote buying to enable Cardoso (and subsequent presidents) to run for reelection (RODRIGUES, 2014). Another stemmed from audio files which suggested that the federal government interfered in the privatization of telecommunication companies (RODRIGUES and LOBATO, 1999).

There were other scandals as well (see Table 2), but few triggered successful prosecution. This is generally thought to be because Geraldo Brindeiro- the person that Cardoso appointed to serve as Chief General Prosecutor-seemed inclined to shelve not-yetcompleted criminal investigations (FREITAS, 2003). As a result, Brindeiro was given the nickname "engavetador-geral," which loosely translates to "shelver-in-chief" (KERCHE and MARONA, 2018).

\section{I.7. Institutional Development: The Office ofthe Comptroller General, the Lista}

Tríplice, and The Federal Police

Because of the apparent impunity observed during the Cardoso administration, in 2002, as the presidential candidate for the Workers' Party, Luiz Inácio Lula da Silva promised voters that he would bring corruption under control (GOLDFRANK and WAMPLER, 2017).

Under Lula's watch, Brazil witnessed a rise in the number of anticorruption audits (FERRAZ and FINAN, 2008) as well as an increase in the number of parliamentary inquiries (i.e., CPIs) into suspected irregularities. Moreover, key government agencies were offered greater support. For instance, the CGU was renamed the Office of the Comptroller General (Controladoria-Geral da União) and was granted new powers and responsibilities (PRAÇA and TAYLOR, 2014; ODILLA, 2020). The Federal Police, which had long prioritized the fight against drug trafficking, was also allocated additional personnel and equipment to counter money laundering and white-collar crime (PONTES and ANSELMO, 2019). 
Also of note, the Lula administration adopted a number of best practices. Namely, in 2003, as a means to protect the MPU's independence against political interference (see the discussion in Section 1.1), Lula was the first president to nominate a new Chief General Prosecutor based on the so-called lista tríplice - i.e., a list of three reputable candidates proposed by the country's federal prosecutors via the Association of National Prosecutors.

\section{I.8. Corruption Scandals: The Lula Administration}

In spite of this progress, the Lula administration still faced a number of corruption scandals, including those known as Bingos / Waldomiro Diniz, Palocci, Sanguessugas, and Navalha (see Table 2; also, again, see footnote 10). However, the scandal which surpassed them all was Mensalão (MICHENER and PEREIRA, 2016).

In an interview with Folha de S.Paulo, then-congressional member Roberto Jefferson claimed that members of Congress were offered periodic payments — which he called mensalão_to secure legislative support for Lula's policy agenda (LO PRETE, 2005). And even though those implicated in Mensalão ${ }^{13}$ were tried by the federal Supreme Court (DOWNIE, 2012), ${ }^{14}$ the Workers' Party won two more presidential elections: the re-election of Lula in 2006 and the election of Dilma Rousseff in 2010.

\section{I.9. Corruption Scandals: The Rousseff Administration}

As Brazil's first female president, Rousseff began her term promoting what became known as faxina ética, an effort which sought to promote an ethical cleaning of sorts (KRAKOVICS, 2014; LIMONGI, 2017). As part of this attempt at promoting government integrity, Rousseff fired six ministers suspected of corruption (ALENCASTRO and BRAGA, 2013). In 2011, she also enacted the Lei de Acesso à Informação, Brazil's freedom of information (FOI) law (RODRIGUES, 2020). When the law was first introduced in Congress, it was explicitly proposed as an anticorruption measure. ${ }^{15}$

Despite the way Rousseff began her presidency, starting in 2013 protesters began taking to the streets to express their dissatisfaction with the quality of public services (GOHN,

13 In the wake of Mensalão, representatives from opposition parties also faced investigations and criminal trials for similar quid pro quo schemes. These particular scandals became known as Mensalão do DEM and Mensalão Tucano, both of which are listed in Table 2.

14 In Brazil, members of parliament, government ministers, the president, the vice president, and members of the higher courts are subject to a special jurisdiction (foro privilegiado). Only the Supreme Court can judge members of this group. See Section 2.8 for further discussion.

15 As explained by Dilma Rousseff and others in the message that accompanied the Lei de Acesso à Informação, "Access to public information [...] is one of the strongest tools for fighting corruption" (ROUSSEFF et al., 2009). 
2014). Many were angry at the billions spent on new football stadiums for the 2014 World Cup (WATTS, 2013). Seemingly in response to the rise in public anger, with Rousseff's support, Congress passed two legislative bills that would allow plea bargaining for criminal law proceedings and leniency agreements with companies for administrative law proceedings (MENDES, 2013; ODILLA, 2018). It is around this time that Lava Jato began to unfold.

In spite of the growing public discontent, Rousseff managed to get re-elected in 2014 for a second term (AMARAL and RIBEIRO, 2018). And, when taking the oath of office in 2015, Rousseff stressed an anticorruption message (see Table 2). However, her message failed to appease the public. Many protested against the government of the Workers' Party and in favor of the Lava Jato Task Force's work, which was closing in on a growing number of politicians (GOHN, 2014; RAMOS et al., 2014; PRAÇA, 2017). It is in this context that Rousseff's administration was cut short by impeachment. ${ }^{16}$ Not long after, Lula was jailed and the evidence of corruption stemming from Lava Jato seemed to fuel political support for the presidential candidacy of Jair Bolsonaro.

\section{Tracking Jair Bolsonaro’s Promises on Corruption Control}

According to a number of surveys, months after Jair Bolsonaro assumed the presidency, Brazilians were still concerned about corruption. One such survey revealed that, between 2018 and 2020, Brazilians grew pessimistic about the fate of accountability in their country. According to that survey, days after Bolsonaro was elected, a majority of the population (56\%) estimated that corruption would soon decrease (XP/IPESPE, 2020). By April of 2020, only a minority (18\%) still held that belief, while many more (45\%) thought that corruption would worsen in the coming months (XP/IPESPE, 2020).

According to a different survey, some two years after Bolsonaro was elected president, approximately 55\% of Brazilians had reached the conclusion that the Bolsonaro administration was no better at fighting corruption than previous ones (MARTINS, 2020; PARANÁ PESQUISAS, 2020). A different survey conducted around the same time showed that a majority of the population in Brazil still perceived corruption in their midst, with approximately 77\% saying that corruption had either increased or remained the same between 2018 and 2020 (CNT/MDA, 2020, p. 25; FUZEIRA, 2020). Given the shifts in popular opinion, it is possible that - two years after the 2018 elections - Brazilians began to sense an incongruence between Bolsonaro's original campaign promises and his actions as president.

16 Rousseff was accused of spending public funds without congressional authorization and was impeached in August, shortly after the 2016 Olympics. Rousseff herself was not accused of corruption (LAGUNES and ROSE-ACKERMAN, 2017). 
With this issue in mind, Tables 3 and 4 highlight eight corruption-related promises that Jair Bolsonaro made between March 29, 2018, and January 7, 2019. Nearly all of the promises listed in these tables were communicated during the campaign season, though one was also communicated as part of Bolsonaro's inaugural speech as president. While these are not all of Bolsonaro's early promises on corruption control, they arguably represent the most important issues that Bolsonaro and his team chose to promote. The promises cover a range of topics - from defending corruption-fighting institutions to firing high-level appointed officials suspected of corruption. In this section, we review each promise, beginning with the promise referring to government transparency. ${ }^{17}$

table 3 - Candidate Jair Bolsonaro's Promises to Fight Corruption (Part 1 of 2)

\begin{tabular}{|c|c|c|c|c|}
\hline TOPIC & SUBTOPIC & DATE & TRANSLATED QUOTE ${ }^{\rho}$ & $\begin{array}{l}\text { NOTABLE ACTIONS OR OMISSIONS } \\
\text { RELATING TO THE CAMPAIGN PROMISE }\end{array}$ \\
\hline \multirow[t]{9}{*}{ TRANSPARENCY } & GOVERNMENT & AUGUST 14, 2018 & “TRANSPARENCY AND & \multirow{9}{*}{$\begin{array}{l}\text { A NUMBER OF PRESIDENT JAIR } \\
\text { BOLSONARO'S ACTIONS HAVE SOUGHT TO } \\
\text { WEAKEN GOVERNMENT TRANSPARENCY, } \\
\text { INCLUDING EXECUTIVE MEASURES THAT } \\
\text { LIMITED THE HANDLING OF FREEDOM OF } \\
\text { INFORMATION (FOI). }\end{array}$} \\
\hline & \multirow[t]{8}{*}{ TRANSPARENCY } & ITWO MONTHS & COMBATING CORRUPTION & \\
\hline & & BEFORE THE & ARE NON-NEGOTIABLE & \\
\hline & & ELECTIONSI & GOALS."1 & \\
\hline & & & & \\
\hline & & JANUARY 7, 2019 & “TRANSPARENCY ABOVE ALL. & \\
\hline & & ISIX DAYS AFTER & ALL OF OUR ACTS WILL HAVE & \\
\hline & & BEING SWORN IN & TO BE OPEN TO THE PUBLIC."2 & \\
\hline & & AS PRESIDENT) & & \\
\hline
\end{tabular}

\begin{tabular}{|c|c|c|c|c|}
\hline INSTITUTIONS OF & SUPPORTING & SEPTEMBER 11, & “SUPPORTING LAVA JATO IS & PRESIDENT JAIR BOLSONARO'S DECISION \\
\hline \multirow[t]{3}{*}{ ACCOUNTABILITY } & THE LAVA JATO & 2018 (A MONTH & FUNDAMENTAL TO THE FIGHT & TO NOMINATE AUGUSTO ARAS TO SERVE AS \\
\hline & TASK FORCE & BEFORE THE & AGAINST CORRUPTION IN & PROSECUTOR GENERAL JEOPARDIZED THE \\
\hline & & ELECTIONSI & BRAZIL."3 & LAVA JATO TASK FORCE. \\
\hline INSTITUTIONS OF & DEFENDING & AUGUST 14, 2018 & “URGENT CHALLENGES: & PRESIDENT JAIR BOLSONARO'S ACTIONS \\
\hline \multirow[t]{8}{*}{ ACCOUNTABILITY } & CORRUPTION- & ITWO MONTHS & WIDESPREAD CORRUPTION & AND INACTIONS HAVE DONE MORE THAN \\
\hline & FIGHTING & BEFORE THE & AND THREATS TO THE & UNDERMINE THE LAVA JATO TASK FORCE. \\
\hline & INSTITUTIONS & ELECTIONS) & INSTITUTIONS THAT ARE & DUE TO A CLAIM THAT HE ILLEGALLY \\
\hline & & & FIGHTING IT."1 & INTERFERED IN THE FEDERAL POLICE, HE \\
\hline & & & & CAME UNDER INVESTIGATION IN THE \\
\hline & & & & SUPREME COURT. AT CRITICAL MOMENTS, \\
\hline & & & & BOLSONARO'S ADMINISTRATION HAS ALSO \\
\hline & & & & FAILED TO SUPPORT THE BRAZILIAN \\
\hline
\end{tabular}

(it continues)

17 Transparency is considered relevant to our line of inquiry based on a core assumption: officials in regimes that embrace transparency realize their actions are subject to review, and therefore are induced to act with greater honesty (LAGUNES, 2021, p. 25). 
FINANCIAL INTELIGENCE UNIT (COAF) AND THE FEDERAL REVENUE SERVICE (RECEITA FEDERAL).

\begin{tabular}{lllll}
\hline MERIT-BASED & COALITION & SEPTEMBER 11, & “[T]O ATTACK CORRUPTION AT & IN AN EFFORT TO WIN LEGISLATIVE \\
APPOINTMENTS & BUILDING & 2018 (A MONTH & ITS ROOT, BY PUTTING AN END & SUPPORT, PRESIDENT BOLSONARO HAS \\
$\&$ DISMISSALS & & BEFORE THE & TO THE GOVERNMENT'S & DELIVERED POSITIONS OF GOVERNMENT \\
& & ELECTIONS) & POLITICAL APPOINTMENTS IN & TO CONGRESSMEN FROM A GROUP \\
& & EXCHANGE FOR SUPPORT.” & CALLED CENTRÃO. \\
\hline
\end{tabular}

${ }^{\rho}$ AUTHORS' TRANSLATION.

${ }^{1}$ BOLSONARO (2018A).

2 CAMPOS AND GONÇALVES (2019).

${ }^{3}$ BOLSONARO (2018B).

Source: Authors.

table 4 - Candidate Jair Bolsonaro’s Promises to Fight Corruption (Part 2 of 2)

\begin{tabular}{llll} 
TOPIC & SUBTOPIC & DATE & TRANSLATED QUOTE $^{\rho}$ \\
\hline MERIT-BASED & FIRING MINISTERS & DECEMBER 2018 & “IF THERE IS ANY EVIDENCE \\
APPOINTMENTS & SUSPECTED OF & ISOON AFTER & OR STRONG CLAIM AGAINST \\
$\&$ DISMISSALS & CORRUPTION & BEING ELECTED & ANYONE WHO IS WITHIN [MY \\
& & PRESIDENT) & PEN'S] REACH, I WILL USE IT."”
\end{tabular}

NOTABLE ACTIONS OR OMISSIONS RELATING TO THE CAMPAIGN PROMISE

IN SPITE OF HIS PROMISE TO BUILD A TEAM OF COLLABORATORS WHO ARE BEYOND REPROACH, ONE OF PRESIDENT JAIR BOLSONARO'S FIRST MINISTERIAL APPOINTMENTS WENT TO ONYX LORENZONI, WHO LATER CONFESSED TO HAVING RECEIVED ILLEGAL FUNDS FROM THE LARGE MEAT PROCESSING COMPANY JBS.

\begin{tabular}{lllll}
\hline RELEVANT & TEN MEASURES & AUGUST 14, 2018 & “WE WILL RESCUE 'THE TEN & JAIR BOLSONARO FAILED TO USE HIS \\
LEGISLATION & AGAINST & (TWO MONTHS & MEASURES AGAINST & INFLUENCE AS PRESIDENT TO SUPPORT \\
& CORRUPTION & BEFORE THE & CORRUPTION', PROPOSED BY & THE TEN MEASURES AGAINST CORRUPTION \\
& ELECTIONS) & THE FEDERAL PROSECUTION & IN CONGRESS. HE ALSO FAILED TO \\
& & SERVICE, AND SUPPORTED & SUPPORT SÉRGIO MORO'S ANTI-CRIME \\
& & BY MILLIONS OF BRAZILIANS, & LEGISLATIVE PROPOSAL, WHICH WAS \\
& & AND SEND IT TO CONGRESS & THOUGHT TO SUPPLANT THE TEN \\
& & FOR APPROVAL."2 & MEASURES. \\
\hline
\end{tabular}

$\begin{array}{llll}\text { RELEVANT } & \text { LIMITING THE } & \text { MARCH 29, 2018 } & \text { “THE IMPRISONMENT MUST } \\ \text { LEGISLATION } & \text { ABILITY OF } & \text { (SEVEN MONTHS } & \text { HAPPEN [AFTER THE } \\ & \text { PRESUMPTIVE } & \text { BEFORE THE } & \text { CRIMINAL SENTENCE IS } \\ & \text { CRIMINALS TO } & \text { ELECTIONS] } & \text { UPHELD] IN THE SECOND } \\ & \text { DELAY JUSTICE } & & \text { INSTANCE.”3 }\end{array}$

PRESIDENT JAIR BOLSONARO DID NOT USE HIS POLITICAL INFLUENCE TO ENSURE THAT THIS MEASURE RECEIVED THE SUPPORT IT NEEDED IN CONGRESS, EVEN THOUGH HIS THEN-MINISTER OF JUSTICE,

(it continues) 
SERGIO MORO, INSISTED THAT IT WAS

CRITICAL TO THE FIGHT AGAINST

CORRUPTION IN BRAZIL.

\begin{tabular}{|c|c|c|c|c|}
\hline RELEVANT & LIMITING & APRIL 27, 2018 & “I SUPPORT THE END OF THE & IN SPITE OF WHAT HE PROMISED, AS \\
\hline \multirow[t]{3}{*}{ LEGISLATION } & POLITICAL & ISIX MONTHS & SPECIAL JURISDICTION...."4 & PRESIDENT, JAIR BOLSONARO HAS NOT \\
\hline & IMMUNITY & BEFORE THE & & PUSHED TO END THE SO-CALLED “FORO \\
\hline & & ELECTIONS) & & PRIVILEGIADO." \\
\hline
\end{tabular}

${ }^{\rho}$ AUTHORS' TRANSLATION.

${ }^{1}$ MONTEIRO, LINDER AND LIMA (2018).

${ }^{2}$ BOLSONARO (2018A).

${ }^{3}$ EDUARDO BOLSONARO (2018).

${ }^{4}$ INTERATIVA FM GOIÂNIA (2018).

Source: Authors.

\section{2. i. Promise to Promote Government Transparency}

First as a presidential candidate, and then as a newly elected president, Jair Bolsonaro prom-

ised to promote transparency in government. ${ }^{18}$ However, many of Bolsonaro's actions have actually served to weaken government transparency. The most conspicuous attempt of this sort occurred in early 2019, only a month after Bolsonaro took office, when his administration issued a decree $(9.690 / 2019)$ that vastly augmented the number of officials allowed to classify information as confidential. Faced with the prospect of greater secrecy, citizens and the press initiated a pressure campaign which ultimately resulted in the decree's overwhelming failure in Congress (BRESCIANI, 2019). This event became part of a pattern of attacks on transparency by the Bolsonaro administration that would eventually end up in failure. Two additional cases stand out as part of this pattern. In the first, the Supreme Court limited the scope of a presidential decree $(9.759 / 2019)$ that opposed the continuation of constitutionally-mandated citizen councils in the federal government. In the second case, the Supreme Court struck down an executive order (Medida Provisória 928/2020) that effectively suspended the legal obligation to respond to FOI requests during the coronavirus pandemic.

After failing to limit the FOI law itself, blackouts - that is, the failure to provide information generally regarded as public - became the administration's tactic of choice. From

18 One of Jair Bolsonaro's key statements on the subject of government transparency was: "Transparência acima de tudo. Todos os nossos atos terão que ser abertos para o público. E o que aconteceu no passado também. Não podemos admitir qualquer cláusula de confidencialidade pretérita. Esses atos e ações tornar-se-ão públicos” (CAMPOS and GONÇALVES, 2019). See Table 3 for the English language translation of the statement. 
the very beginning, Bolsonaro refused to provide logs of visitors to the presidential palace (AMADO, 2019). Blackouts were also used to obscure aspects of the pension reform (DRUMMOND, 2019), the Foreign Service's policies on gender (SOUZA, 2019), the workings of Bolsa Familia (PIRES, 2020a), and police violence (PAGNAN, 2020), among other issues.

The Bolsonaro administration also refused to release studies on the effects of hydroxychloroquine, a drug touted in some corners as a treatment for patients with COVID-19 (PRAZERES, 2020). Moreover, the Bolsonaro administration first restricted, then blacked out, and finally released data on the number of confirmed COVID-19 cases and deaths (LOPES and ONOFRE, 2020). In line with this last example, most blackouts were temporary affairs; however, disclosure delayed is often disclosure denied. For example, the government declared studies on pension reform "restricted" (FABRINI and CARAM, 2019), disclosing them only after the desired legislation had been enacted. ${ }^{19}$

Delaying disclosure through blackouts seems to betray a general disdain for information and those who work to disseminate it. The President's hostility towards the press is reflected in Brazil's significant drop in press freedom rankings (PERRASOLO, 2020). In addition, the President has reserved some of his fiercest criticism for government agencies that report on levels of deforestation and unemployment, among other issues. Accordingly, the administration has slashed funding for the Brazilian Institute for Geography and Statistics (IBGE) (VEJA, 2019) as well as the Brazilian Institute of Environment and Renewable Natural Resources (IBAMA) (DANTAS, 2019), both important disseminators of statistics on socioeconomic and environmental trends, respectively.

Still, in spite of everything described thus far, there have been some advances on the transparency front. In particular, the FOI law has been extended to cover a set of quasi-public corporativist service providers known as the Sistema-S (COSTA and ORDOÑEZ, 2018). As a result, a large tranche of public funding (over USD 30 billion) which finances myriad organizations and activities, from business incubators to centers for skills training, has been opened to public scrutiny.

Additional evidence that the handling of transparency during the Bolsonaro era is not altogether negative is found in FOI data afforded by the Office of the Comptroller General (CONTROLADORIA GERAL DA UNIÃO, 2020). Figure 2 shows annual trends in the number of requests and the celerity of response time (i.e., number of days) since the law took effect in 2012. In 2019, the number of FOI requests increased and response time decreased, both wholly consistent with annual trends. The percentage of FOI requests receiving denials, responses, or differential levels of "user satisfaction" have remained statistically indistinguishable from the annual combined averages of 2012 to 2018. 
Something similar is true for appeals (CONTROLADORIA-GERAL DA UNIÃO, 2020). In effect, there are improvements in the handling of appeals, particularly in terms of CGU decisions that side with requesters. There is also a reduction in the number of appeals resolved due to holdout strategies ${ }^{20}$ by government agencies (MICHENER, SCHWAITZER and CUNHA FILHO, 2020). Although little is known regarding the quality of responses to requests, these statistics could speak favorably of the Bolsonaro administration.

\section{figure 2 - Requests over FOI x Average Response Time by Federal Agencies} (2012-2019)

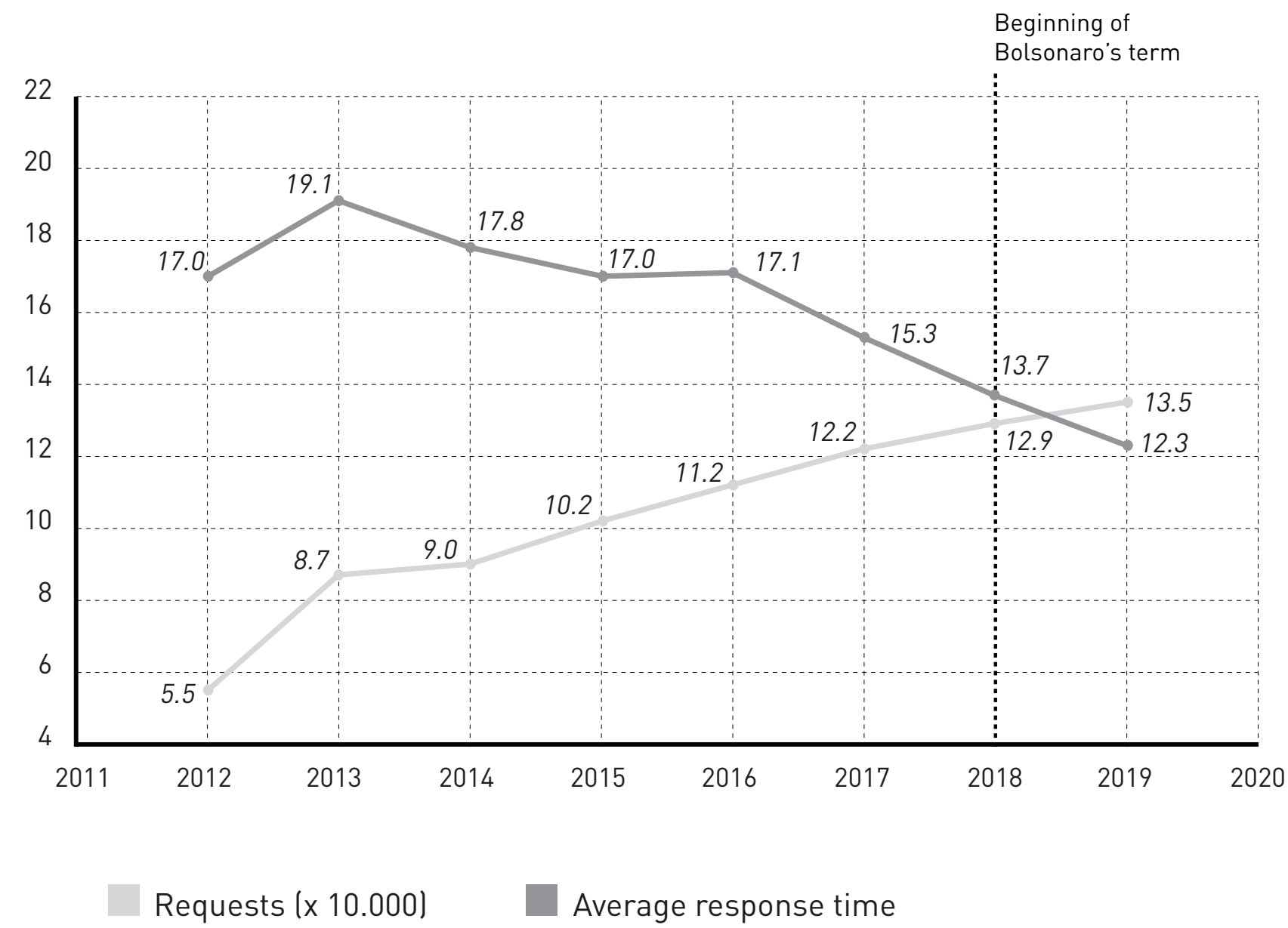

Source: Authors.

However, given the number of transgressions perpetrated against transparency under Bolsonaro, it would be hard to infer that the aforementioned advances are due to positive leadership from the Palácio do Planalto. Moreover, the above data only extend to 2020, and 
criticisms of Bolsonaro's approach to transparency have seemingly increased since the onset of the pandemic. A better indication of consistent or even improved FOI performance might evaluate the internalization and embeddedness of information access practices within the federal administration, the stewardship of the CGU, or even a certain amount of "deep state" bureaucratic activism against the presidency (MICHENER, 2015, p. 85). These questions require further research, but at least this much seems true: Brazil's federal FOI regime appears to be relatively resilient vis-à-vis Bolsonaro's attacks on transparency.

\subsection{Promise to Support the Lava Jato Task Force}

The systematic manner in which President Bolsonaro has challenged transparency is problematic. That said, Bolsonaro's actions regarding transparency are insufficient grounds on which to conclude that he has failed his anticorruption mandate. It is important to track his progress on other relevant promises made during the 2018 campaign season, including his promise regarding the Lava Jato Task Force.

Candidate Jair Bolsonaro assured Brazilian voters that he would support the Task Force. ${ }^{21}$ This is significant because — as was first hinted at in Section 1.2 - the Task Force was recognized to have led an effective investigation into grand corruption (TI, 2016; ALLARD PRIZE, 2017). As part of Operação Lava Jato, the Task Force managed to make 295 arrests, secure 278 convictions, and recover approximately USD 803 million in lost assets (MPF, 2021). As a result, supporting the Task Force was arguably a way to support the fight against corruption in Brazil. However, President Jair Bolsonaro's decision to nominate Augusto Aras to serve as Chief General Prosecutor began a series of events that ultimately jeopardized the Task Force. ${ }^{22}$

In 2019, when President Jair Bolsonaro had the opportunity to appoint a new Chief General Prosecutor to head the MPU, he broke with precedent by ignoring the list of nominees put forth by the Association of National Prosecutors (CONSULTOR JURÍDICO, 2019). ${ }^{23}$ Notably, these nominees had offered to support the Task Force (BARBOSA, 2019; MPF, 2019). In contrast, Bolsonaro's preferred candidate-i.e., Aras_had actually been

21 Jair Bolsonaro's original statement on the Lava Jato Task Force was made on Twitter (BOLSONARO, 2018b). The statement reads as follows: "Apoiar a Lava Jato é fundamental no combate à corrupção no Brasil. O fim da impunidade é uma das frentes que estanca o problema, outra é atacar a corrupção na sua raiz, pondo fim nas indicações políticas do governo em troca de apoio. Nós temos a independência necessária para tal!” See Table 3 for more information.

22 Aras, who holds a Ph.D. in Constitutional Law from the Pontifical Catholic University of São Paulo, is the son of a former legislator and a long-time member of the Federal Prosecution Service (CORREIO DA BAHIA, 2019).

See our brief discussion of the lista tríplice in Section 1.7. 
critical of the Task Force. Aras had argued that the Task Force had attracted too much attention to itself and needed some correcting (CARVALHO and DELLA COLETTA, 2019a; TALENTO, 2019). ${ }^{24}$

After assuming the role of Chief General Prosecutor, Aras began to take actions that seemingly interfered with the Task Force. For one, Aras required that the Task Force share all of its case information - including classified information - with his office (ROCHA, 2020). When Deltan Dallagnol, as head of the Task Force, rejected Aras's blanket request for information, Aras began to criticize the Task Force publicly (ROCHA, 2020). ${ }^{25}$ Aras even asked the Supreme Court to order that the Task Force transfer all case information to his office (FABRINI and TEIXEIRA, 2020). Then, Aras took matters a step further - he sought to dismantle the Task Force (PIRES, 2020b). Ultimately, when Chief General Prosecutor Augusto Aras officially moved to end the Lava Jato Task Force on February 1, 2021, President Jair Bolsonaro offered no opposition. ${ }^{26}$

To be clear, our sense is that there was room to improve the Task Force. Indeed, even as we acknowledge that the Task Force enjoyed widespread popularity as recently as October 2020 (CNT/MDA, 2020 p. 25; FUZEIRA, 2020), adopting certain improvements to its approach seemed reasonable. ${ }^{27}$ We also recognize that, because Operação Lava Jato was bound to end at some point, the question of what to do with the Task Force was destined to come up sooner or later (BULLOCK and STEPHENSON, 2020). Still, there are reasons to take issue with the particular manner in which Augusto Aras handled the Task Force (LEITÃO, 2020; MENDES, 2021). It is similarly concerning to learn that President Jair Bolsonaro claimed to have ended Lava Jato because there was no more corruption in Brazil (ROCHA DE BARROS, 2020). In his words, "I ended [Lava Jato] because there is no more corruption in the government" (FAGUNDES, 2020). ${ }^{\mathbf{2 8}}$

24 In July 2020, Aras said, "It is time to correct the course so that lavajatismo does not endure" (authors' translation). The original statement in Portuguese was: "É hora de corrigir rumos para que o lavajatismo não perdure" (VENAGLIA and LIMA, 2020).

25 Around this time, some of Aras's close associates also began questioning the appropriateness of the Task Force model (PIRES, 2020d).

26 Now that the Lava Jato Task Force has been terminated, it appears as though some of its prosecutors will be transferred to the recently created Special Group Combating Organized Crime (in Portuguese, Grupo de Atuação Especial de Combate ao Crime Organizado or Gaeco). Gaeco will work within the Federal Prosecution Service in the state of Paraná (MPF, 2021; BRITO and SLATTERY, 2021).

27 For a discussion of some of the issues with how Operação Lava Jato was carried out, see: CAMPELLO et al. (2020), and GANLEY and LAGUNES (2020b).

28 In Portuguese, the original statement reads as follows: "Eu acabei com a Lava Jato porque não tem mais corrupção no governo” (DELLA COLETTA, CARVALHO and URIBE, 2020). 
Setting Bolsonaro's misleading statement about Lava Jato to one side, it is worth pointing out that his impact on the Task Force was not solely through his selection of Augusto Aras as Chief General Prosecutor. Bolsonaro was also responsible for choosing leaders in Congress who sought to undermine the Lava Jato Task Force by attempting to limit the powers of prosecutors (SOARES and PIRES, 2020; PIRES and TURTELLI, 2020).

All things considered, it cannot be said that Bolsonaro followed through with his promise to support the Lava Jato Task Force. ${ }^{29}$ Instead, Bolsonaro's shifting position on Lava Jato has seemingly been driven by political convenience (BOGHOSSIAN, 2020).

\subsection{Promiseto Defend Corruption-Fighting Institutions}

While running for president in 2018, Jair Bolsonaro signaled his commitment to support not only the Lava Jato Task Force, but also the other institutions that have participated in the fight against corruption. ${ }^{30}$ This is of consequence considering that much of the recent progress that Brazil has made in promoting government integrity can be attributed precisely to these institutions (e.g., ARANHA, 2020). However, since Bolsonaro took office, many of these institutions have been weakened or subjected to considerable stress. ${ }^{31}$

For instance, during the first year of Bolsonaro's administration, the COAF was relocated several times. First, the financial intelligence unit was granted additional funds and staff when it was placed within the Ministry of Justice. ${ }^{32}$ But around the time it was revealed that the COAF was investigating allegations against President Bolsonaro's eldest son, the agency was moved to the Ministry of Economy and then to the Central Bank (MATAIS, 2019; PORTINARI, 2019; SIMON and SWEIGART, 2020). ${ }^{33}$ Notably, President Bolsonaro also removed the head of the COAF (SIMON, 2019; SIMON and SWEIGART, 2020). ${ }^{\mathbf{3 4}}$

29 A clarifying statement is in order. As far as we can tell, Jair Bolsonaro never openly criticized the Lava Jato Task Force. However, his son, Senator Flávio Bolsonaro, did express support for Aras's actions against the Task Force (CAPELLI and PRADO, 2020).

30 Jair Bolsonaro's original statement about Brazil's accountability institutions was included in his official government plan (BOLSONARO, 2018a). The statement reads as follows: "Desafios urgentes: Corrupção generalizada e ameaças às instituições que a estão combatendo." See Table 3 for additional information.

See Sections 1.5 and 1.7 for a reminder of some of these institutions' basic functions.

32 The COAF's staff increased from thirty-seven to fifty-six (PIRES, 2019).

33 In November 4, 2020, Jair Bolsonaro's eldest son, Flávio Bolsonaro, was formally charged with embezzlement and money laundering in a scheme involving staff members at his former legislative office in the Rio de Janeiro State Assembly (LONDONO, 2020). As of this writing, there are still charges pending against Flávio Bolsonaro (SACONI, 2021; SCHREIBER, 2021).

34 Given the number of disruptive changes affecting the COAF, there were many who voiced concern (DIANNI, 2019; SIMON, 2019; HARRIS, 2020). 
Next, it is worth examining events surrounding the Federal Revenue Service and the Federal Police. Regarding the former, Bolsonaro criticized the agency for what he claimed was the targeting of his relatives (PIRES, FERNANDES and MONTEIRO, 2019). Bolsonaro also ordered the dismissal of key officials within the Federal Revenue Service (PIRES, FERNANDES and MONTEIRO, 2019; SOARES, 2020). With regards to the Federal Police, President Bolsonaro is accused of jeopardizing the agency's autonomy after apparently forcing the removal of key officials and even firing Maurício Valeixo, then head of the agency (LONDOÑO, CASADO and ANDREONI, 2020a; RICHTER, 2020). ${ }^{\mathbf{3 5}}$

In addition to threatening the autonomy of specific agencies, Bolsonaro participated in public demonstrations wherein protestors demanded the closing of both the Supreme Court and Congress (VENCESLAU and LINDNER, 2020; FREITAS, 2020).

Taken together, the evidence suggests that President Bolsonaro has not only failed to protect a number of Brazil's key institutions of accountability, but also directly and indirectly contributed to making them more vulnerable (AVRITZER, 2020; NOBRE, 2020).

\subsection{Promiseto Reject Quid Pro Quo Politics}

As a presidential candidate, Jair Bolsonaro promised that, if elected president, he would avoid trading government jobs for political support. ${ }^{36}$ It was a rejection of what he referred to as "old politics" (ROSE-ACKERMAN and PIMENTA, 2020, p. 205). As he saw it, political appointments nurtured inefficiency and corruption. ${ }^{37}$ And, in fact, there is some research to support this view (e.g., RAUCH and EVANS, 2000). However, over the course of his administration, Bolsonaro has become closer to legislators from Centrão, a group of center and center-right parties that are said to demand positions in government and other government resources in exchange for their support (BOADLE, 2020a; BRAGON, 2020; LONDOÑO, CASADO and ANDREONI, 2020b).

This shift in political alliances became especially apparent during Bolsonaro's second year as president. Bolsonaro risked being impeached, so he began to build a political coalition in Congress that could offer him a measure of protection (BOADLE, 2020a; LONDOÑO, CASADO and ANDREONI, 2020b). Allegedly, Bolsonaro's defense strategy worked as

35 Valeixo's removal is the particular event that seems to have caused Sérgio Moro to resign from his position as Bolsonaro's Minister of Justice (LONDOÑO, CASADO and ANDREONI, 2020a).

36 Jair Bolsonaro's original statement on the question of political appointments was made on Twitter (BOLSONARO, 2018b). The statement reads as follows: "O fim da impunidade é uma das frentes que estanca o problema, outra é atacar a corrupção na sua raiz, pondo fim nas indicações políticas do governo em troca de apoio. Nós temos a independência necessária para tal!” See Table 3 for more information.

37 To quote Bolsonaro, "As indicações políticas levam à ineficiência do Estado e à corrupção" (JORNAL NACIONAL, 2018). 
follows: offer positions in the federal government in exchange for support in Congress (ROSA, 2020). By June of 2020, at least seventeen government posts are said to have been granted to members of Centrão and their allies (PODER360, 2020).

What is more, the coalition in Congress that Bolsonaro built relied on legislators suspected of corruption in Lava Jato, such as Centrão politicians Ciro Nogueira and Arthur Lira (FREIRE, 2019; BRAGON, 2020; D’AGOSTINO, 2020; TEIXEIRA, 2020). ${ }^{38}$ Lira, in particular, was elected to serve as speaker of the lower house of Congress after the Bolsonaro administration lent him much-needed support. In particular, the Bolsonaro administration is accused of offering a number of legislators financial resources for their home states and government jobs for their political allies in exchange for supporting Lira (FRAZÃO, 2020; RESENDE, CHAIB and CARNEIRO, 2020; CHAIB, URIBE and RESENDE, 2020; PIRES and CAMPOREZ, 2021a; PIRES and CAMPOREZ, 2021b). As one journalist points out, Lira's victory in Congress gave Jair Bolsonaro “a base among center-right politicians with whom he had once vowed never to ally" (BOADLE, 2021).

On a somewhat related note, a number of Bolsonaro's former political allies claim that the president attempted to buy political support for his son's bid to serve as ambassador to the United States (CLAVERY and VIVAS, 2019). Even if Bolsonaro's approach to securing legislative support seems technically legal, the Brazilian term toma lá dá cá comes to mind (CAMAROTTI, 2020). This is an expression referring to quid pro quo-precisely the sort of political dealing that Bolsonaro originally promised he would avoid.

\subsection{Promise to Fire Collaborators Suspected of Corruption}

Candidate Bolsonaro also promised to fire any cabinet minister or ministers accused of corruption. ${ }^{39}$ However, in spite of his promise to rely on a team of collaborators that are beyond reproach, one of President Bolsonaro's first high-level appointments went to his longtime political ally Onyx Lorenzoni. Prior to being invited to join Bolsonaro's administration, there were credible allegations that Lorenzoni had received illegal funds-i.e., informal campaign donations_-from the meat processing company JBS (DE LARA, 2018; REUTERS, 2018 ;

Both members of the Progressistas party, Ciro Nogueira and Arthur Lira are - as of this writing - defendants in a Lava Jato case. They are accused of forming a criminal organization with other congressmen to embezzle money from Petrobras (FREIRE, 2019; D’AGOSTINO and OLIVEIRA, 2019; BRAGON, 2020). However, in March 2021, these charges were dismissed by the Second Chamber of the Supreme Court (TEIXEIRA, 2021; MOURA, 2021). Notably, Arthur Lira is also a defendant in another Lava Jato corruption case. He is accused of taking bribes in exchange for sustaining the nomination of the president of a state company (D'AGOSTINO and OLIVEIRA, 2019; AMORIM, 2020).

39 Jair Bolsonaro's original statement on this matter reads as follows: "Havendo qualquer comprovação ou denúncia robusta contra quem quer que seja e que esteja ao alcance da minha caneta Bic, ela será usada” (MONTEIRO, LINDNER and LIMA, 2018). See Table 4 for more information. 
FABRINI, 2020; PIRES, 2020c). When confronted with these allegations, Lorenzoni publicly admitted that he had, in fact, accepted illegal campaign donations from the company (MAZUI, 2017). ${ }^{40}$ However, in spite of the questions surrounding Lorenzoni's reputation, Bolsonaro still chose him to serve as his first chief of staff (CHAGAS, 2018). ${ }^{41}$

Notably, Lorenzoni is not the only one of Bolsonaro's political allies whose reputation has been questioned. The case of Marcelo Álvaro Antônio is also worth discussing.

In 2019, the Brazilian Federal Police indicted Álvaro Antônio on charges of corruption and illegal campaign financing (MATTOSO and BRAGON, 2019; MATTOSO, BRAGON and CANOFRE, 2019). According to the allegations, in 2018, only a few months before Bolsonaro assumed the presidency, Álvaro Antônio embezzled public campaign funds (MATTOSO and BRAGON, 2019). However, these allegations did not stop Bolsonaro from appointing Álvaro Antônio to head the Ministry of Tourism. Bolsonaro even offered the following statement in an effort to downplay the claims against his political ally: "He [Álvaro Antonio] is not facing a dead end. If [the allegations are] serious [...] we will make a decision. He's doing a brilliant job” (authors' translation; MONTEIRO and MATAIS, 2019). ${ }^{\mathbf{4 2}}$

Ultimately, in December 2020, Álvaro Antônio was removed from office. That said, his removal was not in response to the criminal charges against him. Instead, the Brazilian media reports that Álvaro Antônio was removed because of an internal quarrel (PARAGUASSU, 2020; ARAUUJO, 2020; GADELHA, 2020; ORTIZ, 2020). Beyond these, there is also the case of Fábio Wajngarten, President Bolsonaro's former press secretary.

In early 2020, Folha de S.Paulo alleged that a company co-owned by Wajngarten was doing business with companies hired by the federal government, thus raising questions of conflicts of interest (FABRINI and WIZIAK, 2020). Bolsonaro's response to the allegations, however, was not to remove Wajngarten. Instead, Bolsonaro downplayed the matter. "If it was illegal," Bolsonaro suggested, "we will see... But, from what I have seen so far, everything's legal and will continue. He's an outstanding figure. If he were crap, like some people out there, no one would be criticizing him" (authors' translation; FERNANDES, 2020).$^{43}$

40 Later, in August 2020, Onyx Lorenzoni signed a non-prosecution deal with General Prosecutor Augusto Aras in which he confessed to having received some USD 56,000 in illegal campaign donations (FABRINI, 2020; TALENTO, 2020).

41 Bolsonaro eventually removed Onyx Lorenzoni from the position; however, he was then appointed to head the Ministry of Citizenship, and so was not actually expelled from Bolsonaro's administration (BOADLE, 2020b).

42 Bolsonaro's original sentence in Portuguese: "Ele não chegou ao final da linha. Se for algo de grave, substancioso, a gente toma uma decisão. Ele está fazendo um brilhante trabalho” (MONTEIRO and MATAIS, 2019).

43 Bolsonaro's original quote in Portuguese: "Se foi ilegal, a gente vê lá na frente. Mas, pelo que vi até agora, está tudo legal, vai continuar. Excelente profissional. Se fosse um porcaria, igual alguns que tem por aí, ninguém estaria criticando ele" (FERNANDES, 2020). 
In summary, it appears that Bolsonaro has not been as strict with his collaborators as he had promised (CARVALHO, 2020). This has led at least one commentator to conclude that Bolsonaro holds a double standard-according to this commentator, the president is only able to acknowledge his opponents' corruption (SAKAMOTO, 2020).

\subsection{Promise to Support the Ten Measures Against Corruption}

In 2015, as head of the Lava Jato Task Force, Deltan Dallagnol led a movement that sought to pass legal reforms to facilitate prosecution of politicians suspected of corruption (AYRES, 2016; BULLOCK and STEPHENSON, 2020, p. 216). The Ten Measures Against Corruption (or, as it is known in Brazil, Dez Medidas Contra a Corrupção) embodied that reform effort (see footnote 7).

When seeking the presidency, Jair Bolsonaro promised to support the approval of the Ten Measures. ${ }^{44}$ However, Bolsonaro failed to use his influence as president to encourage the approval of the Ten Measures (MATTONI and ODILLA, 2021). Instead, his government proposed broader legislation to fight crime (CALGARO and PALMA, 2019; BULLOCK, 2019)but, even then, Bolsonaro's government failed to ensure that the proposed crime bill passed with the inclusion of key measures related to corruption (CARVALHO and DELLA COLETTA, 2019 b). In particular, the original crime bill was stripped of provisions that promised to curtail irregular campaign financing (BULLOCK and STEPHENSON, 2020, p. 218-219). Moreover, the approved legislation did not ensure the imprisonment of defendants upon losing their first court appeal, a longstanding concern for those who care about limiting impunity in Brazil (ONOFRE, 2019). ${ }^{45}$

To make matters worse, in September of 2019, Bolsonaro enacted a bill that could criminalize some of the work of anticorruption prosecutors, police officers, and judges (FRANCE, 2019). Consequently, while recalling that a president does not have complete control over what is ultimately legislated in Congress, we do not find evidence that Bolsonaro has advocated for the Ten Measures Against Corruption during his time as president.

\subsection{Promise to Limit the Ability of Presumptive Criminals to Delay Justice}

Historically, those accused of corruption in Brazil have tended to avoid jail time (MICHENER and PEREIRA, 2020). One way to solve this would be to reform the law in order to limit

44 Jair Bolsonaro's original statement about the Ten Measures Against Corruption was included in his official government plan (BOLSONARO, 2018a). The statement reads as follows: "Transparência e Combate à Corrupção são metas inegociáveis. Como pilar deste compromisso, iremos resgatar 'As Dez Medidas Contra a Corrupção', propostas pelo Ministério Público Federal e apoiadas por milhões de brasileiros, e encaminhá-las para aprovação no Congresso Nacional." See Table 4 for more information.

See Section 2.8. 
the ability of presumptive criminals, especially those with power and wealth, to delay judicial procedures. In fact, during the 2018 campaign season, Jair Bolsonaro said that he supported jailing defendants as soon as they lost their first court appeal. ${ }^{46}$ This measure is commonly known in Brazil as "second instance" imprisonment.

Encouragingly, in March of 2018, just seven months before the presidential election, then legislator Bolsonaro signed a bill that sought to turn the "second instance" imprisonment measure into law (CÂMARA DOS DEPUTADOS, 2018). However, once elected, Bolsonaro did not actually use his political influence to ensure that the measure received the support it needed in Congress. ${ }^{47}$ Initially, the anticrime bill proposal (see Section 2.6) included "second instance" imprisonment (BARBIÉRI and CALGARO, 2019; CALGARO and PALMA, 2019), but committee representatives in the lower house of Congress moved to discard the measure (ONOFRE, 2019).

Later, when "second instance" imprisonment was again taken up by Congress, the representative of Jair Bolsonaro's government in the Senate, Fernando Bezerra Coelho, sought to delay the discussions (MAIA, 2019). As of this writing, media reports suggest that politicians from Centrão-i.e., Bolsonaro's political allies in Congress - have also worked to delay the discussions about the measure (SARDINHA, 2020). ${ }^{48}$ So, it may be said that, as president, Jair Bolsonaro and his allies have not prioritized the legislative measure that would ensure corrupt officials are jailed after losing their first court appeal.

\subsection{Promiseto Limit Political Immunity}

Foro privilegiado is a special jurisdiction that has historically ensured that certain high-level politicians can only be investigated, prosecuted, and tried by the Supreme Court. Similar to the previous topic (see Section 2.7), foro privilegiado is a legal structure that contributes to sustaining impunity in Brazil, and so doing away with it would help ensure that all citizens enjoy similar rights and obligations before the law. ${ }^{49}$

46 Jair Bolsonaro's original statement on this matter was included in his official government plan (BOLSONARO, 2018a). The statement reads as follows: "A prisão tem que ocorrer em segunda instância" (INTERATIVA FM GOIÂNIA, 2018). See Table 4 for more information.

47 Indeed, those who favored the measure - mainly, former Minister of Justice Sérgio Moro-complained that President Bolsonaro failed to back the anticrime bill (ABRITTA, 2020). Similarly, the newspaper Gazeta do Povo published an editorial complaining that Bolsonaro has remained silent regarding the "second instance" imprisonment measure (GAZETA DO POVO, 2021).

48 Moreover, in February of 2021, when the government sent a list of priorities to Congress, not a single one related to corruption (GAZETA DO POVO, 2021; TURTELLI, WETERMAN and BORGES, 2021).

49 According to Brazilian Supreme Court Justice Edson Fachin, "the so-called foro privilegiado is not compatible with the republican principle," according to which all persons are equal before the law (RICHTER and PONTES, 2017). 
Based on some of his statements, it appeared that Jair Bolsonaro wanted to end foro privilegiado. ${ }^{50}$ However, a similar dynamic to those described previously has also played out here. If Jair Bolsonaro was truly interested in ending foro privilegiado, as president he could encourage Brazilian legislators to discuss and vote for a Constitutional amendment that was approved by the Senate in 2017 (GROBA, 2017). However, he has not done so. Bolsonaro's silence on the matter may be explained by the fact that one of his sons, Senator Flávio Bolsonaro, is — as of this writing - under investigation (SERAPIÃO, 2018; GUIMARÃES and SOARES, 2019). ${ }^{\mathbf{5 1}}$ Senator Flávio Bolsonaro has sought to avoid trial by claiming that he should have special jurisdiction (SARTORI, 2020). In other words, one of Jair Bolsonaro's sons is currently relying on foro privilegiado.

\section{CONCLUSION}

Our guiding assumptions are that political rhetoric matters, and that it is worth tracking whether elected politicians follow through with their campaign promises. That said, it is fair to question whether elected officials should restrict all of their actions to what was expected of them on or around Election Day (MANIN, PRZEWORSKI and STOKES, 1999, p. 22-23). Conditions will change over time, and so elected officials might reasonably diverge from their original proposals precisely to advance their constituents' interests (STOKES, 2001, p. 18). Still, when it comes to the issue of corruption, the dynamic is somewhat unique: the room for legitimate variation between public expectations and policy action is reduced_-after all, surveys consistently find that people everywhere tend to oppose corruption no matter the circumstance (GATTI, PATERNOSTRO and RIGOLINI, 2003; TORGLER and VALEV, 2010; DONG, DULLECK and TORGLER, 2012).

So, one can hardly claim that an elected official who ran on an anticorruption platform and then presented anticorruption as an inaugural priority can remain responsive to the public interest when his decisions in government systematically undermine the anticorruption agenda. Based on our review of President Jair Bolsonaro's actions on anticorruption, we conclude that — at least on this issue — he has failed the Brazilian electorate. Has he promoted

50 Jair Bolsonaro's statement was: "Eu sou favorável sim ao fim do foro privilegiado, mas com a manutenção da prisão em segunda instância” (INTERATIVA FM GOIÂNIA, 2018). See Table 4 for more information.

51 On November 4, 2020, Rio de Janeiro state prosecutors pressed charges against Flávio Bolsonaro for embezzling money from staff members at his former legislative office in the Rio de Janeiro State Assembly (PHILLIPS, 2020b). As a reporter for The New York Times explains:

Investigators say that the president's son ran a scheme known as rachadinha, in which elected officials pocket part of the salary of legislative aides who accept employment on the condition of kicking back part of their pay. The tactic is common in the lower rungs of politics in Brazil. (LONDOÑO, 2020) 
government transparency as he said he would? Has he protected the Lava Jato Task Force and other important anticorruption agencies as he promised? Has he ensured that all government appointments are based on merit, and has he fired close political collaborators who are accused of corruption? The answer is no-Bolsonaro has failed on all these fronts, just as he has failed to secure the sort of anticorruption legislation that he once said he favored.

Our conclusion should strike readers as concerning, especially considering that corruption in Brazil remains a problem. There are probes swirling around the President's very own family and close allies (EIU, 2020; PHILLIPS, 2020a; DW, 2020; LONDOÑO, ANDREONI and CASADO, 2020). One of Jair Bolsonaro's sons is said to be involved in "fake news" campaigns against political opponents, and another son and the first lady have both been implicated in an embezzlement scheme (EIU 2020; LONDOÑO, ANDREONI and CASADO, 2020). In October 2020, Chico Rodrigues, Bolsonaro's deputy leader in the Senate, was the target of an operation dealing with misappropriation of public funds (CASTELLI, 2020; DW, 2020; PHILLIPS, 2020a). ${ }^{\mathbf{2}}$

When all is said and done, it may be that the accusations against Bolsonaro's sons, wife, and associates are proven baseless. Our objective here has not been to assess the validity of these allegations. Instead, our aim has been to examine whether Jair Bolsonaro's campaign promises matched his early actions as president, and we have conducted this examination to test the extent to which he has remained responsive to the Brazilian electorate. But if any reader is unconvinced by our research, consider the stances taken by two well-known organizations. First, in late 2020, the Organized Crime and Corruption Reporting Project warned that Jair Bolsonaro stood out among leaders from around the world for his role in promoting corruption (OCCRP, 2020). Second, the Organisation for Economic Co-operation and Development became sufficiently concerned about events in Brazil that it set up a group to both monitor the country and seemingly apply pressure in favor of anticorruption efforts (SANCHES, 2021). And so, we end this article by restating our conclusion: the evidence shows that, two years into his presidency, Jair Bolsonaro has failed the anticorruption mandate that he set for himself during the 2018 campaign season.

\section{ACKNOWLEDGMENTS}

The authors would like to thank Kevin Davis, Mariana

Mota Prado, Marta Rodriguez Machado, Raquel de Mattos

52 After the raid, Rodrigues resigned from his post as vice leader and was temporarily suspended from the Senate by the Supreme Court (CASTELLI, 2020). 
Pimenta, Matthew Taylor, Cortney Newell, Flávia Furlan Nunes, and the anonymous reviewers for their feedback. They also want to thank Louisa Ong for her valuable contribution to this study.

\section{REFERENCES}

ABRANCHES, S. Presidencialismo de coalizão: o dilema institucional brasileiro. Dados, v. 31, n. 1, p. 5-34, 1988.

ABREU, A. A. O que é o Ministério Público? Rio de Janeiro: Editora FGV, 2010.

ABRITTA, P. Exclusivo: Moro critica aliança com ‘Centrão' e diz que Bolsonaro não apoiou o combate à corrupção. TV Globo, Rio de Janeiro, 24 May 2020. Available at: https://g1.globo.com/fantastico/ noticia/2020/05/24/exclusivo-moro-critica-alianca-com-centrao-e-diz-que-bolsonaro-nao-apoiouo-combate-a-corrupcao.ghtml. Accessed on: 17 Apr. 2021.

ALENCASTRO, C.; BRAGA, I. Ministros demitidos estão de volta da faxina ética de Dilma. O Globo, Rio de Janeiro, 9 March 2013. Available at: https://oglobo.globo.com/brasil/ministros-demitidosestao-de-volta-da-faxina-etica-de-dilma-7794170. Accessed on: 17 Apr. 2021.

ALLARD PRIZE. Car Wash Task Force (Força Tarefa da Lava Jato). Allard Prize for International Integrity, Vancouver, 2017. Available at: https: / / www.allardprize.org/recipient-and-honourable-mentions/carwash-task-force-forca-tarefa-da-lava-jato. Accessed on: 17 Apr. 2021.

AMADO, G. Governo Bolsonaro decreta sigilo sobre visitas no Palácio da Alvorada. Época, Brasília, 28 Aug. 2019. Available at: https: / / epoca.globo.com/guilherme-amado/governo-bolsonaro-decretasigilo-sobre-visitas-no-palacio-da-alvorada-23909255. Accessed on: 17 Apr. 2021.

AMARAL, O.; RIBEIRO, P. F. Por que Dilma de novo? Uma análise exploratória do estudo eleitoral brasileiro de 2014. In: FIGUEIREDO, A. C.; BORBA, F. (ed.). 25 Anos de Eleições Presidenciais no Brasil. Curitiba: Appris, 2018.

AMORIM. F. STF: $1^{\text {a }}$ Turma tem maioria para manter líder do Centrão Arthur Lira como réu. UOL, Brasília, 24 Nov. 2020. Available at: https: / / noticias.uol.com.br/politica/ultimas-noticias/2020/11/ 24/stf-1-turma-tem-maioria-para-manter-lider-do-centrao-arthur-lira-como-reu.htm. Accessed on: 6 Feb. 2021. 
AMORIM, F. STF aceita denúncia e Collor se torna réu na Lava Jato. UOL, Brasília, 22 Aug. 2017. Available at: https: / / noticias.uol.com.br/politica/ultimas-noticias/2017/08/22/stf-aceita-denunciae-collor-se-torna-reu-na-lava-jato.htm. Accessed on: 17 Apr. 2021.

ARANHA, A. L. Lava Jato and Brazil's Web of Accountability Institutions: A Turning Point for Corruption Control? In: LAGUNES, P.; SVEJNAR, J. (ed.). Corruption and the Lava Jato Scandal in Latin America. New York: Routledge, 2020.

ARANHA, A. L. The Web of Accountability Institutions and Corruption Control in Brazil. In: OECD Global Anti-Corruption \& integrity Forum, 2018, Paris. France: OECD, 2018. Available at: https: / /www. oecd.org/corruption/integrity-forum/academic-papers/Aranha.pdf. Accessed on: 17 Apr. 2021.

ARANTES, R. B. Como uma inédita triangulação na Justiça Criminal produziu a interceptada Lava Jato. Época, Brasília, 13 June 2019. Available at: https:/ / epoca.globo.com/como-uma-inedita-triangulacaona-justica-criminal-produziu-interceptada-lava-jato-23736093. Accessed on: 17 Apr. 2021.

ARANTES, R. B. The Federal Police and the Ministério Público. In: POWER, T. J.; TAYLOR, M. M. (ed.). Corruption and Democracy in Brazil:The Struggle for Accountability. Notre Dame: University of Notre Dame Press, 2011a.

ARANTES, R. B. Polícia Federal e construção institucional. In: FILGUEIRAS, F.; AVRITZER, L. (ed.). Corrupção e sistema político no Brasil. Rio de Janeiro: Civilização Brasileira, 2011b.

ARANTES, R. B. The Brazilian "Ministério Publico" and political corruption in Brazil. In: Promoting Human Rights through good governance in Brazil, 2004, Oxford. United Kingdom: Centre for Brazilian Studies, University of Oxford, 2003. Available at: https://www.lac.ox.ac.uk/sites/default/files/ lac/documents/media/rogerio20arantes2050.pdf. Accessed on: 17 Apr. 2021.

ARANTES, R. B. Ministério Público e Política no Brasil. São Paulo: Editora Sumaré, 2002.

ARAÚJJ, C. Ministro do Turismo acusa Ramos de traição e de querer dar pasta ao Centrão. UOL, Brasília, 9 Dec. 2020. Available at: https://economia.uol.com.br/colunas/carla-araujo/2020/12/09/ministrodo-turismo-chamou-ramos-de-traira-e-demissao-deve-sair-hoje.htm. Accessed on: 17 Apr. 2021.

AURÉliO, D. R. A Extraordinária História do Brasil.Volume 3. Os tempos atuais: Brasil República. São Paulo: Universo dos Livros, 2010.

AVRITZER, L. Política e antipolítica: a crise do governo Bolsonaro. São Paulo: Todavia, 2020. 
AVRITZER, L.; BIGNOTTO, N.; GUIMARÃES, J.; STARLING, H. (ed.). Corrupção: ensaios e críticas. Belo Horizonte: UFMG, 2008.

AYRES, C. Ten Measures Proposed by the Brazilian Federal Prosecution Service to Fight Corruption (Part I). FCPAméricas Blog, Brazil, 30 Dec. 2016. Available at: http: / /fcpamericas.com/english/brazil/ ten-measures-proposed-brazilian-federal-prosecution-service-fight-corruption-part-i/ . Accessed on: 17 Apr. 2021.

BARBIÉRI, L. F. MPF prorroga força-tarefa da Operação Greenfield por um ano. G1, Brasília, 4 Dec. 2018. Available at: https://g1 globo.com/politica/noticia/2018/12/04/mpf-prorroga-forca-tarefada-operacao-greenfield-por-mais-um-ano.ghtml. Accessed on: 17 Apr. 2021.

BARBIÉRI, L. F.; CALGARO, F. Moro apresenta projeto anticorrupção e antiviolência com alterações em 14 leis. G1, Brasília, 4 Feb. 2019. Available at: https://g1.globo.com/politica/noticia/2019/02/ 04/moro-apresenta-a-governadores-projeto-anticrime-com-14-alteracoes-em-leis.ghtml. Accessed on: 17 Apr. 2021.

BARBOSA, B. Lava Jato, Greenfield e Zelotes defendem lista tríplice para reconduzir PGR. UOL, São Paulo, 5 June 2019. Available at: https: / / noticias.uol.com.br/politica/ultimas-noticias/2019/06/05/lavajato-greenfield-e-zelotes-declaram-apoio-a-lista-triplice-para-pgr.htm. Accessed on: 17 Apr. 2021.

BASÍLIO, A. Os maiores escândalos de corrupção do Brasil. Época Negócio, São Paulo, 31 March 2015. Available at: https: / / epocanegocios.globo.com/Informacao/Dilemas/noticia/2015/03/os-maioresescandalos-de-corrupcao-do-brasil.html. Accessed on: 17 Apr. 2021.

BIBLIOTECA DA PRESIDÊNCIA DA REPÚBLICA. Brasília, DF: Presidência da República, n. d. Available at: http: / /www.biblioteca.presidencia.gov.br/presidencia/ex-presidentes. Accessed on: 10 Oct. 2020.

BOADLE, A. Bolsonaro allies win control of Brazilian Congress. Reuters, Brasília, 1 Feb. 2021. Available at: https://www.reuters.com/article/us-brazil-politics/bolsonaro-allies-win-control-of-braziliancongress-idUSKBN2A12WY?il=0. Accessed on: 17 Apr. 2021.

BOADLE, A. As coronavirus crisis saps his popularity, Brazil's Bolsonaro courts former foes. Reuters, Brasília, 12 May 2020a. Available at: https: / /www.reuters.com/article/us-brazil-politics-bolsonaroanalysis / as-coronavirus-crisis-saps-his-popularity-brazils-bolsonaro-courts-former-foes-idUSKBN22O 31Z .Accessed on: 17 Apr. 2021.

BOADLE, A. Brazil's Bolsonaro militarizes his inner Cabinet. Reuters, Brasília, 13 Feb. 2020b. Available at: https: / /www.reuters.com/article/us-brazil-politics-idUSKBN2072S5. Accessed on: 17 Apr. 2021. 
BOGHOSSIAN, B. Conveniência política dita relação entre Bolsonaro e a Lava Jato. Folha de S.Paulo, Brasília, 7 Oct. 2020. Available at: https:/ /www1 folha.uol.com.br/colunas/bruno-boghossian/2020/ 10/conveniencia-politica-dita-relacao-entre-bolsonaro-e-a-lava-jato.shtml. Accessed on: 17 Apr. 2021.

BOLSONARO, E. Jair Bolsonaro fala sobre a prisão em $2^{a}$ instância. São Paulo: Jovem Pan, 2018. 1 video (1 minute). Available at: https://www.youtube.com/watch?v=6N-PzihUnv4. Accessed on: 17 Apr. 2021.

BOLSONARO, J. O caminho da prosperidade: proposta de Plano de Governo. Divulgação de Candidaturas e Contas Eleitorais TSE, 2018a. Available at: http://divulgacandcontas.tse.jus.br/candidaturas/oficial/ 2018/BR/BR/2022802018/280000614517//proposta_1534284632231.pdf. Accessed on: 17 Apr. 2021.

BOLSONARO, J. Apoiar a Lava Jato é fundamental no combate à corrupção no Brasil [...]. Brasília, 11 Sep. 2018b. Twitter: @jairbolsonaro. Available at: https://twitter.com/jairbolsonaro/status/103964005114 2074369. Accessed on: 17 Apr. 2021.

BONFIM, J. B. B. Palavra de presidente: Os discursos presidenciais de posse, de Deodoro a Lula. LGE Editora, 2008. Available at: https: / /www2.senado.leg.br/bdsf/bitstream/handle/id/91988/palavra_ de_presidente.pdf. Accessed on 18 Apr. 2021.

BRAGON, R. Recém-aliado a Bolsonaro, Centrão é suspeito de usar apoio e cargos para obter propina. Folha de S.Paulo, Brasília, 8 May 2020. Available at: https: / /www1.folha.uol.com.br/poder/2020/05/ recem-aliado-a-bolsonaro-centrao-e-suspeito-de-usar-apoio-e-cargos-para-obter-propina.shtml. Accessed on: 17 Apr. 2021.

BRAZIL. Medida Provisória 928, 23 Mar. 2020. Altera a Lei n 13.979, de 6 de fevereiro de 2020, que dispõe sobre as medidas para enfrentamento da emergência de saúde pública de importância internacional decorrente do coronavírus responsável pelo surto de 2019, e revoga o art. 18 da Medida Provisória ${ }^{\circ}$ 927, de 22 de março de 2020. Brasília, DF: Presidência da República, 2020. Available at: http: / /www. planalto.gov.br/ccivil_03/_ato2019-2022/2020/Mpv/mpv928.htm. Accessed on: 25 Sep. 2020.

BRAZIL. Decreto $n^{\circ}$ 9.690, 23 Jan. 2019. Altera o Decreto $n^{\circ}$ 7.724, de 16 de maio de 2012, que regulamenta a Lei ${ }^{\circ}{ }^{\circ}$ 12.527, de 18 de novembro de 2011 - Lei de Acesso à Informação. Brasília, DF: Presidência da República, 2019a. Available at: http://www.planalto.gov.br/ccivil_03/_ato2019-2022/2019/decreto/ d9690.htm. Accessed on: 10 Apr. 2020.

BRAZIL. Decreto n 9.759, 11 Apr. 2019. Extingue e estabelece diretrizes, regras e limitações para colegiados da administração pública federal. Brasília, DF: Presidência da República, 2019b. Available at: http: / /www.planalto.gov.br/ccivil_03/_ato2019-2022/2019/decreto/D9759.htm. Accessed on: 10 Apr. 2020. 
BRAZIL. Lei complementar n 75, 20 May 1993. Dispõe sobre a organização, as atribuições e o estatuto do Ministério Público da União. Brasília, DF: Presidência da República, 1993. Available at: http: //www. planalto.gov.br/ccivil_03/leis/LCP/Lcp75.htm. Accessed on: 17 Apr. 2021.

BRESCIANI, E. Câmara aprova urgência de projeto para revogar decreto do governo sobre sigilo de documentos. O Globo, Brasília, 19 Feb. 2019. Available at: https: / / oglobo.globo.com/brasil/camaraaprova-urgencia-de-projeto-para-revogar-decreto-do-governo-sobre-sigilo-de-documentos-23464190. Accessed on: 17 Apr. 2021.

BRITO, R.; SLATTERY, G. After seven years, Brazil shuts down Car Wash anti-corruption squad. Reuters, Brasília, 3 Feb. 2021. Available at: https://www.reuters.com/article/us-brazil-corruption-idUSKBN2A4068. Accessed on: 10 Dec. 2020.

BULLOCK, J. Proposed Changes in Brazil's Anticorruption Legislation: A Summary and Critique. The Global Anticorruption Blog, 18 March 2019. Available at: https:/ /globalanticorruptionblog.com/2019/03/18/ proposed-changes-in-brazils-anticorruption-legislation-a-summary-and-critique/ . Accessed on: 17 Apr. 2021.

BULLOCK, J.; STEPHENSON, M. How Should Lava Jato End? In: LAGUNES, P.; SVEJNAR, J. (ed.). Corruption and the Lava Jato Scandal in Latin America. New York: Routledge, 2020.

CALGARO, F.; PALMA, G. Ministros Moro e Onyx entregam à Câmara dos Deputados pacote anticrime do governo. G1, Brasília, 19 Feb. 2019. Available at: https: / g1 globo.com/politica/noticia/2019/02/ 19/moro-e-onyx-entregam-pacote-anticrime-a-camara-dos-deputados.ghtml. Accessed on: 17 Apr. 2021.

CÂMARA DOS DEPUTADOS. Biografia Jair Bolsonaro. Brasília, DF: Câmara dos Deputados, n.d. Available at: https://www.camara.leg.br/deputados/74847/biografia. Accessed on: 17 Apr. 2021.

CÂMARA DOS DEPUTADOS. Relatório de conferência de assinaturas da Proposta de Emenda à Constituição 409/2018. Brasília, DF: Câmara dos Deputados, 2018. Available at: https: / www.camara. leg.br/proposicoesWeb/prop_mostrarintegra?codteor=1648067\&filename=Tramitacao-PEC+409/2018. Accessed on: 17 Apr. 2021.

CÂMARA DOS DEPUTADOS. Projeto de Lei no 3.855/2019. Brasília, DF: Câmara dos Deputados, 2019. Available at: https://www.camara.leg.br/proposicoesWeb/fichadetramitacao?idProposicao= 2080604. Accessed on: 17 Apr. 2021.

CAMARGOS, D. Judge upholds request by Daniel Dantas's company to evict 212 families in Pará. Repórter Brasil. September 30, 2019. Available at: https://reporterbrasil.org.br/2019/09/judgeupholds-request-by-daniel-dantass-company- to-evict-212-families-in-para/. Accessed on: 10 Apr. 2020. 
CAMAROTTI, G. No momento em que Bolsonaro intensifica 'toma-lá-dá-cá' com Centrão, avaliação do Congresso piora. G1, Brasília, 17 Aug. 2020. Available at: https://g1.globo.com/politica/blog/gersoncamarotti/post/2020/08/17/no-momento-em-que-bolsonaro-intensifica-toma-la-da-ca-com-centrao-ava liacao-do-congresso-piora.ghtml. Accessed on: 10 Apr. 2021.

CAMPBELL, K. K; JAMIESON, K. H. Rhetoric and Public Address. In: M. J. MacDonald (ed.). The Oxford Handbook of Rhetorical Studies. New York: Oxford University Press, 2017.

CAMPELLO, D. et al. Captured Media? Examining Brazilian Coverage of Lava Jato. In: LAGUNES, P.; SVEJNAR, J. (ed.). Corruption and the Lava Jato Scandal in Latin America. New York: Routledge, 2020.

CAMPOS, A. C.; GONÇALVES, C. Bolsonaro quer transparência em atos dos governos atual e anteriores. Agência Brasil, Brasília, 7 Jan. 2019. Available at: https: / /agenciabrasil.ebc.com.br/politica / noticia / 2019-01 / bolsonaro-quer-transparencia-em-atos-dos-governos-atual-e-anteriores. Accessed on: 17 Apr. 2021.

CAPELLI, P.; PRADO, T. Entrevista exclusiva: Flávio Bolsonaro critica Lava-Jato e defende atuação de Aras. O Globo, Brasília, 5 Aug. 2020. Available at: https://oglobo.globo.com/brasil/entrevista-exclusivaflavio-bolsonaro-critica-lava-jato-defende-atuacao-de-aras-1-24568258. Accessed on: 17 Apr. 2021.

CARSON, L.; PRADO, M. M. Mapping Corruption and Its Institutional Determinants in Brazil. International Research Initiative on Brazil and Africa (IRIBA), Manchester, 2014. Available at: https: / / assets. publishing.service.gov.uk/media/57a089efed915d3cfd0004d6/IRIBA_WP08_Mapping_Corruption_and _its_Institutional_Derminants_in_Brazil.pdf. Accessed on: 17 Apr. 2021.

CARVAlHO, C. Brazil: Recovery Reform Opportunity. Washington, DC: Brazil-U.S. Business Council, 2016. Available at: https: / /www.brazilcouncil.org/wp-content/uploads/2016/05/Brazil-RecoveryReform-Opportunity___pdf. Accessed on: 17 Apr. 2021.

CARVALHO, D. Bolsonaro diz que dará voadora no pescoço de quem praticar corrupção em seu governo. Folha de S.Paulo, Brasília, 14 Oct. 2020. Available at: https://www1.folha.uol.com.br/poder/2020/10/ bolsonaro-diz-que-dara-voadora-no-pescoco-de-quem-praticar-corrupcao-em-seu-governo.shtml. Accessed on: 17 Apr. 2021.

CARVALHO, D.; DELLA COLETTA, R. Brazil's New Attorney General Suggests Changes in the Car Wash Operation. Folha de S.Paulo, 26 Sep. 2019a, sec. Brazil. Available at: https://www1.folha.uol.com.br/ internacional/en/brazil/2019/09/brazils-new-attorney-general-suggests-changes-in-the-car-wash-operation. shtml. Accessed on: 17 Apr. 2021. 
CARVAlHO, D.; DELla COLETTA, R. Senado aprova versão desidratada de pacote anticrime de Moro. Folha de S.Paulo, Brasília, 11 Dec. 2019b. Available at: https:/ /www1.folha.uol.com.br/cotidiano/ 2019/12/senado-aprova-versao-desidratada-de-pacote-anticrime-de-moro.shtml. Accessed on: 17 Apr. 2021.

CARVALHO, J. M. Passado, presente e futuro da corrupção brasileira. In: AVRITZER, L.; BIGNOTTO, N.; GUIMARÃES, J.; STARLING, Heloísa (ed.). Corrupção: ensaios e críticas. Belo Horizonte: UFMG, 2008.

CASTELLI, A. Brazilian Senator Allegedly Found with Cash in His Underwear During Police Raid. CNN, United States, 16 Oct. 2020. Available at: https: / / www.cnn.com/2020/10/16/americas/hfrbrazil-police-cash-chico-rodrigues-jair-bolsonaro-intl/index.html. Accessed on: 17 Apr. 2021.

CHAGAS, P. V. Saiba quem é Onyx Lorenzoni, aliado de primeira hora de Bolsonaro. Agência Brasil, Brasília, 31 Oct. 2018. Available at: https: / /agenciabrasil.ebc.com.br/politica/noticia/2018-10/saibaquem-e-onyx-lorenzoni-aliado-de-primeira-hora-de-bolsonaro. Accessed on: 17 Apr. 2021.

CHAIB, J.; URIBE, G.; RESENDE, T. Governo Bolsonaro barra liberação de emendas e condiciona dinheiro a voto em Lira na eleição da Câmara. Folha de S.Paulo, Brasília, 8 Dec. 2020. Available at: https: / / www1 folha.uol.com.br/poder/2020/12/governo-bolsonaro-barra-liberacao-de-emendase-condiciona-dinheiro-a-voto-em-lira-na-eleicao-da-camara.shtml. Accessed on: 8 Feb. 2021.

CHEMIM, R. Mãos Limpas e Lava Jato: a corrupção se olha no espelho. Porto Alegre: CDG, 2017.

CHILD, D. Who Is Jair Bolsonaro, Brazil's New Far-Right President? Al Jazeera, Rio de Janeiro, 1 Jan. 2019. Available at: https: //www.aljazeera.com/news/2019/01/01/who-is-jair-bolsonaro-brazilsnew-far-right-president/. Accessed on: 17 Apr. 2021.

CLAVERY, E.; VIVAS, F. Líder do PSL diz que Bolsonaro tentou comprar deputados com cargos para beneficiar o filho. G1 , Brasília, 18 Oct. 2019. Available at: https://g1.globo.com/politica/noticia/2019/ 10/18/lider-do-psl-diz-que-bolsonaro-tentou-comprar-deputados-com-cargos-para-beneficiar-o-filho. ghtml. Accessed on: 10 Dec. 2020.

CNT/MDA. Pesquisa CNT de Opinião 2020, Rodada 147. Brasília, DF: CNT/MDA, 2020. Available at: https: / / cdn.cnt.org.br/diretorioVirtualPrd/31867232-a15a-448e-b064-b538a34f9256.pdf. Accessed on: 17 Apr. 2021.

CONSULTOR JURÍDICO. Em setembro, Bolsonaro quebrou tradição e nomeou PGR fora da lista tríplice. Consultor Jurídico, São Paulo, 30 Dec. 2019. Available at: https:/ /www.conjur.com.br/2019dez-30/setembro-bolsonaro-quebrou-tradicao-nomeou-pgr-fora-lista. Accessed on: 17 Apr. 2021. 
COntroladoria-geral DA UNião. Painel Lei de Acesso À Informação Pública. Brasília, DF: Controladoria Geral da União, 2020. Available at: http:/ / paineis.cgu.gov.br/lai/index.htm. Accessed on: 17 Apr. 2021.

CORREIO DA BAHIA. Indicado para PGR, baiano Augusto Aras busca apoio de senadores. Correio da Bahia, Salvador, 7 Sep. 2019. Available at: https: / / www.correio24horas.com.br/noticia/nid/indicadopara-pgr-baiano-augusto-aras-busca-apoio-de-senadores. Accessed on: 17 Apr. 2021.

COSTA, D.; ORDOÑEZ, R. “Tem que meter a faca no Sistema S”, diz Paulo Guedes. O Globo, Rio de Janeiro, 17 Dec. 2018. Available at: https://oglobo.globo.com/economia/tem-que-meter-faca-nosistema-diz-paulo-guedes-23311287. Accessed on: 17 Apr. 2021.

D’AGOSTINO, R. Maioria da $1^{\mathrm{a}}$ Turma do STF rejeita recurso de Arthur Lira, acusado de corrupção; decisão é adiada. G1, Brasília, 24 Nov. 2020. Available at: https://g1.globo.com/politica/noticia/ 2020/11/24/maioria-na-1a-turma-do-stf-vota-contra-recurso-de-arthur-lira-sobre-denuncia-decisaoe-adiada.ghtml. Accessed on: 30 Nov. 2020.

D’AGOSTINO, R.; OLIVEIRA, M. $1^{\text {a }}$ Turma do STF torna deputado Arthur Lira réu por corrupção passiva; defesa contesta. G1, Brasília, 8 Oct. 2019. Available at: https: / g1 .globo.com/politica/noticia/ 2019/10/08/primeira-turma-do-supremo-torna-arthur-lira-reu-por-corrupcao.ghtml. Accessed on: 8 Nov. 2020.

DANTAS, D. Ibama corta 22\% das ações de fiscalização previstas. O Globo, São Paulo, 10 Sep. 2019. Available at: https:/ / oglobo.globo.com/sociedade/ibama-corta-22-das-acoes-de-fiscalizacao-previstas23937584. Accessed on: 17 Apr. 2021.

DAVIS, K. E. Between Impunity and Imperialism:The Regulation of Transnational Bribery. New York: Oxford University Press, 2019.

DE LARA, B. The Corruption Cabinet. The Intercept, United States, 9 Dec. 2018. Available at: https: / / theintercept.com/2018/12/09/brazil-jair-bolsonaro-cabinet/. Accessed on: 17 Apr. 2021.

DELLA COLETTA, R.; CARVALHO, D.; URIBE, G. Eu acabei com a Lava Jato porque não tem mais corrupção no governo, diz Bolsonaro. Folha de S.Paulo, Brasília, 7 Oct. 2020. Available at: https:// www1. folha.uol.com.br/poder/2020/10/bolsonaro-diz-que-lava-jato-acabou-porque-governo-naotem-mais-corrupcao.shtml. Accessed on: 17 Apr. 2021.

DIANNI, C. Mudanças no Coaf podem afetar cooperação internacional contra o crime. Correio Braziliense, Brasília, 28 Aug. 2019. Available at: https:/ /www.correiobraziliense.com.br/app/noticia/politica/2019/ 
08/28/interna_politica,779485/mudancas-no-coaf-podem-afetar-cooperacao-internacional-contra-ocrime.shtml. Accessed on: 10 Apr. 2021.

DONG, B.; DULLECK, U.; TORGLER, B. Conditional corruption. Journal of Economic Psychology, v. 33, n. 3, p. 609-627, 2012.

DOS SANTOS, W. G. A democracia impedida: o Brasil no século XXI. Rio de Janeiro: Editora FGV, 2017.

DOWNIE, A. Brazil targets corruption in "trial of the century". The Christian Science Monitor, São Paulo, 15 Aug. 2012. Available at: https:/ / www.csmonitor.com/World/Americas/2012/0815/Brazil-targetscorruption-in-trial-of-the-century. Accessed on: 17 Apr. 2021.

DOWNS, A. An economic theory of democracy. New York: Harper Collins Publishers, 1957.

DRUMMOND, C. Pesquisadores descobrem trapaça do governo em cálculos da reforma da Previdência. Carta Capital, 17 Sep. 2019. Available at: https://www.cartacapital.com.br/economia/pesquisadoresdescobrem-trapaca-do-governo-em-calculos-da-reforma-da-previdencia. Accessed on: 17 Apr. 2021.

DW. Brazil Senator Caught Hiding Money "between Buttocks”. DeutscheWelle, 15 Oct. 2020. Available at: https://www.dw.com/en/brazil-senator-caught-hiding-money-between-buttocks/a-55291992. Accessed on: 17 Apr. 2021.

EIU. The Economist Intelligence Unit's Country Report: Brazil. London: Economist Intelligence Unit, Oct. 2020.

FABRINI, F. Onyx admite caixa dois da JBS e pagará R\$ 189 mil para encerrar investigação. Folha de S.Paulo, 3 Aug. 2020. Available at: https:/ / www1 folha.uol.com.br/poder/2020/08/onyx-admite-caixa-dois-dajbs-e-pagara-r-189-mil-para-encerrar-investigacao.shtml. Accessed on: 17 Apr. 2021.

FABRINI, F.; CARAM, B. Governo decreta sigilo sobre estudos que embasam reforma da Previdência. Folha de S.Paulo, Brasília, 21 Apr. 2019. Available at: https://www.folha.uol.com.br/mercado/2019/04/governodecreta-sigilo-sobre-estudos-que-embasam-reforma-da-previdencia.shtml. Accessed on: 17 Apr. 2021.

FABRINI, F.; TEIXEIRA, M. Toffoli obriga Lava Jato a compartilhar todos os dados com a PGR. Folha de S.Paulo, Brasília, 9 July 2020. Available at: https: / /www1.folha.uol.com.br/poder/2020/07/toffoliobriga-lava-jato-a-compartilhar-todos-os-dados-com-a-pgr.shtml. Accessed on: 17 Apr. 2021.

FABRINI, F.; WIZIAK, J. Chefe da Secom recebe dinheiro de emissoras e agências contratadas pelo governo Bolsonaro. Folha de S.Paulo, Brasília, 15 Jan. 2020. Available at: https:/ /www1.folha.uol.com.br/poder/ 
2020/01/ chefe-da-secom-recebe-dinheiro-de-emissoras-e-agencias-contratadas-pelo-governo-bolsonaro. shtml. Accessed on: 17 Apr. 2021.

FAGUNDES, M. Bolsonaro Says Brazil Is Corruption-Free, Ends Carwash Probe. Bloomberg, 7 Oct. 2020. Available at: https://www.bloomberg.com/news/articles/2020-10-07/bolsonaro-declares-brazilcorruption-free-and-ends-carwash-probe. Accessed on: 17 Apr. 2021.

FALCÃO, J. et al. V Relatório Supremo em Números: o foro privilegiado e o Supremo. Rio de Janeiro: FGV Direito Rio, 2017. Available at: http: //hdl.handle.net/10438/18097. Accessed on: 17 Apr. 2021.

FERNANDES, T. "Se foi ilegal, a gente vê lá na frente", diz Bolsonaro sobre chefe da Secom. Folha de S.Paulo, Brasília, 16 Jan. 2020. Available at: https: / / www1 .folha.uol.com.br/poder/2020/01/bolsonaroataca-folha-e-diz-que-chefe-da-secom-permanece-no-cargo.shtml. Accessed on: 17 Apr. 2021.

FERNANDES, T. Bolsonaro diz que pode usar caneta Bic se houver denúncia robusta contra Onyx. Folha de S.Paulo, Brasília, 5 Dec. 2018. Available at: https: / /www1 folha.uol.com.br/poder/2018/12/bolsonarodiz-que-pode-usar-caneta-bic-se-houver-denuncia-robusta-contra-onyx.shtml. Accessed on: 17 Apr. 2021.

FERRAZ, C.; FINAN, F. Exposing corrupt politicians: The effects of Brazil's publicly released audits on electoral outcomes. Quarterly Journal of Economics, v. 123. n. 2, p. 703-745, May 2008.

FIGUEIREDO, A. C. The Collor Impeachment and Presidential Government in Brazil. In: LLANOS, M.; MARSTEINTREDET, L. (ed.). Presidential Breakdowns in Latin America: Causes and Outcomes of Executive Instability in Developing Democracies. New York: Palgrave Macmillan, 2010.

FIGUEIREDO, A. C.; LIMONGI, F. Instituições políticas e governabilidade: desempenho do governo e apoio legislativo na democracia brasileira. In: MELO, C. R.; SÁEZ, M. A. (ed.). A Democracia Brasileira: Balanco e Perspectivas para o Seculo 21. Belo Horizonte: Editora UFMG, 2007.

FILGUEIRAS, S.; VALE, A. M. Mantidos os segredos dos anões. IstoÉ, Brasília, 25 Sep. 2002. Available at: https: / / istoe.com.br/25780_MANTIDOS+OS+SEGREDOS+DOS+ANOES/. Accessed on: 17 Apr. 2021.

FIORI, M. Saiba mais sobre as CPIs do Orçamento (1993) e da Corrupção (1988). Agência Brasil, Brasília, 4 Aug. 2006. Available at: http://memoria.ebc.com.br/agenciabrasil/noticia/2006-08-04/saiba-maissobre-cpis-do-orcamento-1993-e-da-corrupcao-1988. Accessed on: 17 Apr. 2021.

FLEISHER, D. V. Corruption in Brazil: Defining, Measuring, and Reducing. A report of the CSIS Americas Program. Washington, DC: Center for Strategic \& Int'l Studies, 2002. 
FOLHA DE S.PAULO. Entenda a Operação Vampiro. Folha de S.Paulo, São Paulo, 25 Sep. 2006. Available at: https://www1.folha.uol.com.br/folha/brasil/ult96u83791.shtml. Accessed on: 17 Apr. 2021.

FOLHA DE S.PAULO. Doleiros movimentaram quase US\$ 2,5 bi no RJ e em SP. Folha de S.Paulo, Rio de Janeiro, 18 Aug. 2004. Available at: https://www1.folha.uol.com.br/folha/brasil/ult96u63382.shtml. Accessed on: 17 Apr. 2021.

FOLHA DE S.PAULO. Privatização das teles foi seguida por escândalos. Folha de S.Paulo, São Paulo, 29 July 2003. Available at: https://www1.folha.uol.com.br/folha/dinheiro/ult91u70988.shtml. Accessed on: 17 Apr. 2021.

FOLHA DE S.PAULO. Hargreaves volta hoje à Casa Civil. Folha de S.Paulo. Brasília, 8 Feb. 1994a. Available at: https: / /www1.folha.uol.com.br/fsp/1994/2/08/brasil/12.html. Accessed on: 17 Apr. 2021.

FOLHA DE S.PAULO. Denúncia motivou CPI em 1988. Folha de S.Paulo, São Paulo, 20 Nov. 1994b. Available at: https: / / www1.folha.uol.com.br/fsp/1994/11/20/brasil/29.html. Accessed on: 17 Apr. 2021.

FRANCE, G. Brazil: Setbacks in the legal and institutional anti-corruption frameworks. Berlin:Transparency International, 2019. Available at: https: / / www.transparency.org/en/publications/brazil-setbacks-inthe-legal-and-institutional-anti-corruption-frameworks. Accessed on: 17 Apr. 2021.

FRAZÃO, F. Ramos articula apoio a Lira e oferece emendas. O Estado de S. Paulo, Brasília, 11 Dec. 2020. Available at: https: / / politica.estadao.com.br/noticias/geral,ramos-articula-apoio-a-lira-e-oferece-emendas, 70003547903. Accessed on: 7 Feb. 2021.

FREIRE, M. Conheça dez histórias de corrupção durante a ditadura militar. UOL, São Paulo, 1 Apr. 2015. Available at: https: / / noticias.uol.com.br/politica/ultimas-noticias/2015/04/01/conheca-dezhistorias-de-corrupcao-durante-a-ditadura-militar.htm. Accessed on: 17 Apr. 2021.

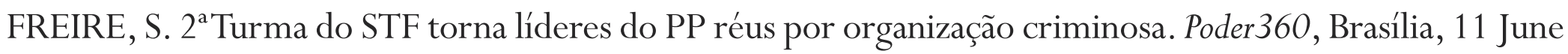
2019. Available at: https:/ / www.poder360.com.br/lava-jato/2a-turma-do-stf-torna-lideres-do-pp-reuspor-organizacao-criminosa. Accessed on: 17 Apr. 2021.

FREITAS, J. Concorrência da ferrovia Norte-Sul foi uma farsa. Folha de S.Paulo, São Paulo, 13 May 1987. Available at: https:/ /www1.folha.uol.com.br/folha/80anos/marcos_do_jornalismo-03.shtml. Accessed on: 17 Apr. 2021.

FREITAS, S. "Engavetador” é apelido injusto, diz Brindeiro. Folha de S.Paulo, Brasília, 7 June 2003. Available at: https://www1.folha.uol.com.br/fsp/brasil/fc0706200313.htm. Accessed on: 17 Apr. 2021. 
FREITAS, T. Maskless Bolsonaro Joins Protesters Against Congress, Court. Bloomberg, 31 May 2020. Available at: https: / /www.bloomberg.com/news/articles/2020-05-31/bolsonaro-joins-protesters-against-congressand-supreme-court. Accessed on: 17 Apr. 2021.

FUZEIRA, V. Lava Jato: 84\% dos brasileiros defendem continuidade da operação. Metrópoles, Brasília, 26 Oct. 2020. Available at: https://www.metropoles.com/brasil/lava-jato-84-dos-brasileiros-defendemcontinuidade-da-operacao. Accessed on: 17 Apr. 2021.

GADELHA, I. Bolsonaro decide demitir ministro do Turismo, Marcelo Álvaro Antônio. CNN Brasil, Brasília, 9 Dec. 2020. Available at: https:/ / www.cnnbrasil.com.br/politica/2020/12/09/bolsonaro-deve-demitirministro-do-turismo-marcelo-alvaro-antonio. Accessed on: 17 Apr. 2021.

GANLEY, K.Y.; LAGUNES, P. Lava Jato's Lessons, Leaks, and Lasting Impacts. In: LAGUNES, P.; SVEJNAR, J. (ed.). Corruption and the Lava Jato Scandal in Latin America. New York: Routledge, 2020a.

GANLEY, K.Y.; LAGUNES, P. An Interview with Glenn Greenwald. In: LAGUNES, P.; SVEJNAR, J. (ed.). Corruption and the Lava Jato Scandal in Latin America. New York, NY: Routledge, 2020b.

GASPAR, M. A Organização: a Odebrecht e o esquema de corrupção que chocou o mundo. Rio de Janeiro: Cia das Letras, 2020.

GATTI, R.; PATERNOSTRO, S.; RIGOLINI, J. Individual Attitudes Towards Corruption: Do Social Effects Matter? World Bank Policy Research Working Paper, Washington, 2003.

GAZETA DO POVO. A prioridade que não entrou na lista. Gazeta do Povo, Curitiba, 6 Feb. 2021. Available at: https://www.gazetadopovo.com.br/opiniao/editoriais/prisao-segunda-instancia-prioridade/. Accessed on: 17 Apr. 2021.

GEDDES, B.; RIBEIRO NETO, A. Institutional Sources of Corruption in Brazil. ThirdWorld Quarterly, v. 13, n. 4, p. 641-661, 1992.

GOHN, M. G. A sociedade brasileira em movimento: vozes das ruas e seus ecos políticos e sociais. Caderno CRH, v. 27, n. 71, p. 431-441, 2014.

GOLDFRANK, B.; WAMPLER, B. Good Government and Politics as Usual? The Schizophrenic Path of the Workers' Party. In: KINGSTONE, P.; POWER, T. J. (ed.). Democratic Brazil Divided. Pittsburgh: University of Pittsburgh Press, 2017, p. 53-74. 
GOMES, P. H. Operação Greenfield denuncia 29 ex-gestores de fundos de pensão por gestão temerária. G1, Brasília, 9 Jan. 2020. Available at: https://g1.globo.com/politica/noticia/2020/01/09/ operacao-greenfield-denuncia-29-ex-gestores-de-fundos-de-pensao-por-gestao-temeraria.ghtml. Accessed on: 17 Apr. 2021.

GONDIM, A. Rosane Collor depõe hoje em Brasília. Folha de S.Paulo, Brasília, 9 June 1997. Available at: https://www1.folha.uol.com.br/fsp/brasil/fc090621.htm. Accessed on: 17 Apr. 2021.

GROBA, P. Senado aprova o fim do foro privilegiado, que segue para a Câmara. Senado Notícias, Brasília, 31 May 2017. Available at: https: / /www12.senado.leg.br/noticias/materias/2017/05/31/senado-aprova-ofim-do-foro-privilegiado-que-segue-para-a-camara. Accessed on: 17 Apr. 2021.

GUIMARÃES, A.; SOARES, P. R. Coaf aponta que Flávio Bolsonaro recebeu 48 depósitos suspeitos em 1 mês, no total de R \$ 96 mil. Jornal Nacional, Brasília, 18 Jan. 2019. Available at: https://g1.globo.com/rj/ rio-de-janeiro/noticia/2019/01/18/coaf-aponta-que-em-1-mes-foram-feitos-48-depositos-suspeitos-aflavio-bolsonaro-no-total-de-r-96-mil.ghtml. Accessed on: 17 Apr. 2021.

HARRIS, B. Brazil criticised for backtracking on terror funding fight. Financial Times, Brasília, 3 Feb. 2020. Available at: https: / /www.ft.com/content/1 fa9e73c-3ec5-11ea-a01a-bae547046735. Accessed on: 17 Apr. 2021.

HELAL FILHO, W. Há 20 anos, Bolsonaro defendeu fechamento do Congresso e a morte de então presidente, Fernando Henrique. Blog do acervo O Globo, Rio de Janeiro, Rio de Janeiro, 24 May 2019, sec. Blog do Acervo. Available at: https: / / blogs.oglobo.globo.com/blog-do-acervo/post/ha-20-anosbolsonaro-defendeu-fechamento-do-congresso-e-morte-do-entao-presidente-fernando-henrique-cardoso. html. Accessed on: 17 Apr. 2021.

HOUS, D. S. Bolsonaro diz que ministros com acusações contundentes deverão deixar governo. Folha de S.Paulo, São Paulo, 14 Nov. 2018. Available at: https: / /www1.folha.uol.com.br/poder/2018/11/ bolsonaro-diz-que-ministros-com-acusacoes-contundentes-deverao-deixar-governo.shtml. Accessed on: 17 Apr. 2021.

INTERATIVA FM GOIÂNIA. Entrevista Bolsonaro na IN \#InterativaLive. Goiânia: Interativa FM, 2018. 1 video (155 minutes). Available at: https: / / www.youtube.com/watch?v=QLECVKqfuJQ. Accessed on: 9 Dec. 2020.

JORNAL NACIONAL. Bolsonaro diz que Ministério da Saúde terá dinheiro para investimentos ao acabar com indicação partidária e corrupção. TV Globo, Rio de Janeiro, 19 Oct. 2018. Available at: https: / /g1.globo.com/politica/eleicoes/2018/noticia/2018/10/19/bolsonaro-diz-que-ministerio- 
da-saude-tera-dinheiro-para-investimentos-ao-acabar-com-indicacao-partidaria-e-corrupcao.ghtml. Accessed on: 10 Dec. 2020.

KERCHE, F. Autonomy and discretionary power of the Public Prosecutor's Office in Brazil. Dados, Rio de Janeiro, v. 4, Selected Edition, 2008. Available at: http: / / socialsciences.scielo.org/scielo.php?

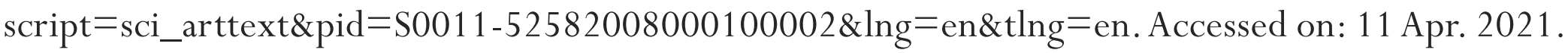

KERCHE, F.; MARONA, M. O Ministério Público na Operação Lava Jato: Como eles chegaram até aqui? In: KERCHE, F.; FERES JÚNIOR, J. (coord.). Operação Lava Jato e a Democracia Brasileira. São Paulo: Editora Contracorrente, 2018. p. 69-100.

KRAKOVICS, F. Primeiro mandato de Dilma começou com faxina ética e termina com escândalo na Petrobras. O Globo, Brasília, 31 Dec. 2014. Available at: https://oglobo.globo.com/brasil/primeiromandato-de-dilma-comecou-com-faxina-etica-termina-com-escandalo-na-petrobras-14940078. Accessed on: 20 Oct. 2020.

LAGUNES, P. The Eye \& theWhip: Corruption Control in the Americas. New York, NY: Oxford University Press, 2021.

LAGUNES, P. An Interview with Deltan Dallagnol. In: LAGUNES, P.; SVEJNAR, J. (ed.). Corruption and the Lava Jato scandal in Latin America. New York: Routledge, 2020.

LAGUNES, P.; ROSE-ACKERMAN, S. Why Brazil Is Winning Its Fight against Corruption. The Conversation, 2 Feb. 2017, sec. Economy + Business. Available at: https://theconversation.com/whybrazil-is-winning-its-fight-against-corruption-71968. Accesses on: 2 Apr. 2021.

LEAHY, J.; SCHIPANI, A. Jair Bolsonaro Draws in Brazil Populists Despite Contradictions. The Financial Times. 17 Sep. 2018, sec. Brazil. Available at: https: / /www.ft.com/content/d7df60cc-b7c4-11e8-bbc3ccd7de085ffe. Accessed on: 13 Nov. 2020.

LEITÃO, M. A corrupção sempre presente. O Globo, Rio de Janeiro, 16 Oct. 16 2020. Available at: https: / / blogs.oglobo.globo.com/miriam-leitao/post/corrupcao-sempre-presente.html. Accessed on: 13 Dec. 2020.

LIMONGI, F. Impedindo Dilma. Novos Estudos - CEBRAP; São Paulo, Special Issue, p. 5-13, Jun. 2017. Available at: http://dx.doi.org/10.25091/S01013300201700040001. Accessed on: 15 Nov. 2020.

LONDOÑO, E. Bolsonaro's Eldest Son, a Senator, Faces Graft Charges in Brazil. New York Times, Rio de Janeiro, 4 Nov. 2020. Available at: https://www.nytimes.com/2020/11/04/world/americas/flaviobolsonaro-charges.html. Accessed on: 15 Dec. 2020. 
LONDOÑO, E.; ANDREONI, M. We'll Dig Graves: Brazil's New Leaders Vow to Kill Criminals. The New York Times, Rio de Janeiro, 1 Nov. 2018, sec. Race \& Policing. Available at: https://www.nytimes. com/2018/11/01/world/americas/bolsonaro-police-kill-criminals.html. Accessed on: 13 Dec. 2020.

LONDONO, E.; ANDREONI, M.; CASADO, L. 'A Family Business:' Graft Investigation Threatens Brazil's Bolsonaro. The New York Times, Rio de Janeiro, 28 Aug. 28 2020, sec. Americas. Available at: https://www. nytimes.com/2020/08/28/world/americas/brazil-bosonaro-corruption.html. Accessed on: 15 Dec. 2020. LONDOÑO, E.; CASADO, L.; ANDREONI, M. Turmoil in Brazil: Bolsonaro Fires Police Chief and Justice Minister Quits. The New York Times, Rio de Janeiro, 24 Apr. 2020a, sec. Americas. Available at: https://www.nytimes.com/2020/04/24/world/americas/brazil-bolsonaro-moro.html. Accessed on: 24 Jul. 2020.

LONDOÑO, E.; CASADO, L.; ANDREONI, M. Bolsonaro Fights for Survival, Turning to Empowered Military Elders. New York Times, Rio de Janeiro, 1 May 2020b, sec. Americas. Available at: https: / / www.nytimes.com/2020/05/01/world/americas/brazil-bolsonaro-coronavirus-crisis.html. Accessed on: 24 Jul. 2020.

LOPES, R.; ONOFRE, R. Gestão Bolsonaro acumula ao menos 13 medidas para reduzir transparência oficial. Folha de S.Paulo, Brasília, 21 Jun. 21 2020. Available at: https://www1.folha.uol.com.br/ poder/2020/06/gestao-bolsonaro-acumula-ao-menos-13-medidas-para-reduzir-transparencia-oficial. shtml. Accessed on: 20 Nov. 2020.

LO PRETE, R. Jefferson denuncia mesada paga pelo tesoureiro do PT. Folha de S.Paulo, São Paulo, 6 Jun. 6, 2005. Available at: https://www1.folha.uol.com.br/fsp/brasil/fc0606200502.htm. Accessed on: 8 Nov. 2020.

LUPA. Jair Bolsonaro eleito: veja aqui 110 frases ditas por ele e checadas pela Lupa em 2018. Folha de S.Paulo, Rio de Janeiro, 28 Oct. 28 2018, sec. Lupa. Available at: https://piaui.folha.uol.com.br/lupa/2018/10/ 28/tudo-sobre-bolsonaro. Accessed on: 17 Apr. 2021.

MAIA, G. Líder do governo Bolsonaro recolhe assinaturas para atrasar projeto da prisão em $2^{a}$ instância. O Globo, Brasília, 11 Dec. 11 2019, sec. Brasil. Available at: https://oglobo.globo.com/brasil/lider-dogoverno-bolsonaro-recolhe-assinaturas-para-atrasar-projeto-da-prisao-em-2-instancia-24131717. Accessed on: 10 Dec. 2020

MANIN, B.; PRZEWORSKI, A.; STOKES, S. Introduction. In: PRZEWORSKI, A.; STOKES, S; MANIN, B (ed.). Democracy, Accountability, and Representation. Cambridge: Cambridge University Press, 1999. p. 1-26. 
MARQUES, L. Dilma afasta cúpula do Ministério dos Transportes envolvida em esquema de propina. VEJA. 2 Jul. 2011. Available at: https://veja.abril.com.br/politica/dilma-afasta-cupula-do-ministeriodos-transportes-envolvida-em-esquema-de-propina/. Accessed on: 5 Oct. 2020.

MARTINS, H. Combate à corrupção: 54\% dos brasileiros acham que Bolsonaro trabalhou menos ou igual aos governos anteriores, diz pesquisa. Estado de Minas, Belo Horizonte, 17 Aug. 2020. Available at: https://www.em.com.br/app/noticia/politica/2020/08/17/interna_politica,1176919/corrupcao-para54-bolsonaro-fez-menos-ou-igual-governos-anteriores.shtml. Accessed on: 17 Apr. 2021.

MATAIS, A. Bolsonaro diz não se opor a tirar o Coaf de Moro e devolver para Ministério da Economia. O Estado de S. Paulo, Brasília, 25 Apr. 2019. Available at: https://politica.estadao.com.br/noticias/ geral,bolsonaro-diz-nao-se-opor-em-tirar-o-coaf-de-moro-e-devolver-para-ministerio-da-economia, 70002804011 Accessed on: 2 Dec. 2020.

MATAIS, A. et al. “Anões do Orçamento” fizeram Odebrecht mudar estratégia no Congresso, diz delator. O Estado de S.Paulo, São Paulo, 12 Dec. 2016. Available at: https:/ / politica.estadao.com.br/blogs/faustomacedo/anoes-do-orcamento-fizeram-odebrecht-mudar-estrategia-no-congresso-diz-delator. Accessed on: 10 Apr. 2021.

MATTONI, A. and ODILLA, F. Digital media, activism, and social movements' outcomes in the policy arena. The case of two anti-corruption mobilizations in Brazil. Working Paper, 2021.

MATTOSO, C.; BRAGON, R. Ministro do Turismo é indiciado pela PF em investigação de esquema de laranjas do PSL. Folha de S.Paulo, Brasília, 4 Oct. 2019. Available at: https://www1.folha.uol.com. $\mathrm{br} /$ poder/2019/10/ministro-do-turismo-e-indiciado-pela-pf-em-investigacao-de-esquema-de-laranjasdo-psl.shtml. Accessed on: 5 Jul. 2020.

MATTOSO, C.; BRAGON, R.; CANOFRE, F. Federal Police Requests New Investigation into Campaign Finances of Minister of Tourism. Folha de S.Paulo, Brasília, 7 Oct. 2019. https: / /www1.folha.uol.com.br / internacional/en/brazil/2019/10/federal-police-requests-new-investigation-into-campaign-finances-ofminister-of-tourism.shtml. Accessed on: 5 Jul. 2020.

MAZUI, G. Deputado Onyx Lorenzoni admite ter recebido dinheiro de caixa 2 da JBS. Rádio Gaúcha, Brasília, 19 May 2017. Available at: https: / / gauchazh.clicrbs.com.br/politica/noticia/2017/05/deputadoonyx-lorenzoni-admite-ter-recebido-dinheiro-de-caixa-2-da-jbs-9796726.html. Accessed on: 10 Jul. 2020.

MELO, M. A.; PEREIRA, C. Making BrazilWork: Checking the President in a Multiparty System. New York, NY: Palgrave Macmillan, 2013. 
MENDES, C. H. Aras é a antessala de Bolsonaro no Tribunal Penal Internacional. Folha de S.Paulo, São Paulo, 26 Jan. 2021. Available at: https://www1.folha.uol.com.br/amp/colunas/conrado-hubner-mendes/ 2021/01/aras-e-a-antessala-de-bolsonaro-no-tribunal-penal-internacional.shtml. Accessed on: 10 Feb. 2021.

MENDES, P. Dilma sanciona sem vetos lei que define organização criminosa. G1, Brasília, 2 Aug. 2013. Available at: g1.globo.com/politica/noticia/2013/08/dilma-sanciona-sem-vetos-lei-que-defineorganizacao-criminosa.html. Accessed on: 15 Apr. 2021.

MICHENER, G. How Cabinet Size and Legislative Control Shape the Strength of Transparency Laws. Governance, v. 28, n. 1, p. 77-94, 2015. Available at: https://doi.org/10.1111/gove.12075. Accessed on: 2 Feb. 2021.

MICHENER, G.; PEREIRA, C. A Great Leap Forward for Democracy and the Rule of Law? Brazil's Mensalão Trial. Journal of Latin American Studies, v. 48. 3. p. 477-507, 2016.

MICHENER, G.; SCHWAITZER, B.; CUNHA FILHO, M. Conspicuous Noncompliance withTransparency Regimes: Lessons from Brazil. Working Paper, 2020.

MONTEIRO, T.; MATAIS, A. “Economia é 100\% com o Guedes e não tem plano B”, diz Bolsonaro. O Estado de S. Paulo, Brasília, 5 Oct. 2019. Available at: https: / / politica.estadao.com.br/noticias/geral, economia-e100-com-o-guedes-e-nao-tem-plano-b-diz-bolsonaro,70003038726. Accessed on: 18 Sep. 2020.

MONTEIRO, T.; LINDNER, J.; LIMA, L. Bolsonaro titubeia, mas fala em usar 'caneta Bic' em caso de “denúncia robusta” contra Onyx. O Estado de S. Paulo, Brasília, 5 Dec. 2018. Available at: https:/ / politica. estadao.com.br/noticias/geral,bolsonaro-titubeia-mas-fala-em-usar-caneta-bic-em-caso-de-denunciarobusta-contra-onyx,70002634448. Accessed on: 30 Sep. 2021.

MORENO, J. B. A incômoda companhia dos escândalos: casos de corrupção estouraram em todos os governos. O Globo, Rio de Janeiro, 15 Mar. 2015. Available at: https://oglobo.globo.com/brasil/aincomoda-companhia-dos-escandalos-casos-de-corrupcao-estouraram-em-todos-os-governos-15598762. Accessed on: 12 Oct. 2020.

MOTTA, S. STF absolve Collor de crime da época em que era presidente. Folha de S.Paulo, Brasília 24 Apr. 2014. Available at: https://m.folha.uol.com.br/poder/2014/04/1445021-stf-absolve-collor-decrime-da-epoca-em-que-era-presidente.shtml. Accessed on: 30 Jan. 2021.

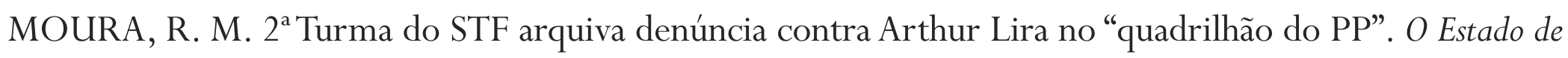
S. Paulo, Brasília, 2 Mar. 2021. Available at: https: / politica.estadao.com.br/blogs/fausto-macedo/gilmarmendes-vota-para-arquivar-denuncia-contra-arthur-lira-no-quadrilhao-do-pp/. Accessed on: 10 Apr. 2021. 
MPF. Lava Jato passa a integrar o Grupo de Ação Especial de Combate ao Crime Organizado no Paraná. Ministério Público Federal, Paraná, 3 Feb. 2021. Available at: www.mpf.mp.br/pr/sala-de-imprensa/noticiaspr/lava-jato-passa-a-integrar-o-gaeco-no-parana. Accessed on: 15 Apr. 2021.

MPF. Forças-tarefas da Lava Jato, Greenfield e Zelotes destacam importância da lista tríplice na escolha de novo PGR. Ministério Público Federal, Paraná, 5 Jun. 2019. Available at: http:/ /www.mpf.mp.br/pr/salade-imprensa/noticias-pr/forcas-tarefas-da-lava-jato-greenfield-e-zelotes-destacam-importancia-da-lista-tri plice-na-escolha-de-novo-pgr. Accessed on: 12 Dec. 2020.

MPF. MPF/PR: balanço sobre o Caso Banestado. Ministério Público Federal, 9 Jun. 2008. Available at: http: / / www.mpf.mp.br/pr/sala-de-imprensa/noticias-pr/mpf-pr-balanco-sobre-o-caso-banestado. Accessed on: 5 Oct. 2020.

MPF. Operação Farol da Colina prende doleiros em todo o país. Ministério Público Federal, 17 Aug. 2004. Available at: http: / /www.mpf.mp.br/mg/sala-de-imprensa/noticias-mg/201010071636080300-operacaofarol-da-colina-prende-doleiros-em-todo-o-pais. Accessed on: 5 Oct. 2020.

MURELLO, P. Brazil Scandal: '7 Dwarfs', Huge Cash Payoffs - Officials Accused of Milking Millions From Federal Budget. Associated Press, 1993. Available at: from: https://archive.seattletimes.com/archive/ ?date $=19931024 \& \operatorname{slug}=1727756$. Accessed on: 17 Apr. 2021.

NOBRE, M. Ponto-Final: A Guerra de Bolsonaro Contra a Democracia. São Paulo: Todavia, 2020.

OCCPR. Jair Bolsonaro 2020 Person of the Year in Organized Crime and Corruption. Available at: from: https: / / www.occrp.org/en/poy/2020/. Accessed on: 17 Apr. 2021.

O’DONNEL, G. A. Delegative Democracy. Journal of Democracy, v. 5, n. 1, p. 55-69, Jan. 1994.

ODILLA, F. Oversee and Punish: Understanding the Fight Against Corruption Involving Government Workers in Brazil. Politics and Governance, v. 8, n. 2, p. 140-152, May 2020.

ODILLA, F. 5 anos depois, o que aconteceu com as reivindicações dos protestos que pararam o Brasil em junho de 2013. BBC News Brasil, London, 9 Jun. 2018. Available at: https:/ /www.bbc.com/portuguese/ brasil-44353703. Accessed on: 15 Apr. 2021.

ONOFRE, R. Deputados retiram prisão em $2^{a}$ instância de pacote de Moro. O Estado de S. Paulo, Brasília, 9 Jul. 2019. Available at: https: / / politica.estadao.com.br/noticias/geral, grupo-de-trabalhoda-camara-rejeita-proposta-de-prisao-apos-condenacao-em-2-instancia,70002914370. Accessed on: 8 Jul. 2020. 
ORTIZ, D. Mensagem de Álvaro Antônio em grupo de ministros diz que Ramos pediu demissão dele a Bolsonaro. TV Globo, Brasília, 9 Dec. 2020. Available at: https://g1.globo.com/politica/noticia/ 2020/12/09/mensagem-de-alvaro-antonio-em-grupo-de-ministros-diz-que-ramos-pediu-demissaodele-a-bolsonaro.ghtml. Accessed on: 9 Feb. 2021.

PAGNAN, R. Governo Bolsonaro exclui violência policial de relatório sobre violações de direitos humanos. Folha de São Paulo, São Paulo, 12 Jun. 2020. Available at: https://www1.folha.uol. com.br/cotidiano/2020/06/governo-bolsonaro-exclui-violencia-policial-de-relatorio-sobre-violacoesde-direitos-humanos.shtml. Accessed on: 8 Oct. 2020.

PARAGUASSU, L. Brazil's Bolsonaro fires tourism minister over quarrel - source. Reuters, Brasília, 9 Dec. 2020. Available at: https: / / finance.yahoo.com/news/brazils-bolsonaro-fires-tourism-minister180702855.html. Accessed on: Feb 8. 2021.

PARANÁ PESQUISAS. Pesquisa de Opinião Pública Nacional. Instituto Paraná Pesquisas. 2020. Available at: https://www.paranapesquisas.com.br/wp-content/uploads/2020/08/MidiaBR_Ago20.pdf. Accessed on: 17 Apr. 2021.

PERRASOLO, J. Brasil cai em ranking mundial de liberdade de imprensa pelo $2^{\circ}$ ano seguido. Folha de S.Paulo, São Paulo, 21 Apr. 21 2020. Available at: https: / /www1.folha.uol.com.br/mundo/2020/ 04/brasil-cai-em-ranking-mundial-de-liberdade-de-imprensa-pelo-20-ano-seguido.shtml. Accessed on: 20 Sep. 2020.

PHILLIPS, T. Police Find Cash Hidden between Bolsonaro Ally's Buttocks. The Guardian, Rio de Janeiro, 15 Oct. 2020a. Available at: https://www.theguardian.com/world/2020/oct/15/brazil-police-cashjair-bolsonaro-ally-buttocks-chico-rodrigues. Accessed on: 6 Feb. 2021.

PHILIPS, T. Prosecutors in Brazil file embezzlement charges against Jair Bolsonaro's son. The Guardian, Rio de Janeiro, 4 Nov. 2020b. Available at: https://www.theguardian.com/world/2020/nov/04/ brazil-president-jair-bolsonaros-son-flavio-accused-of-embezzlement. Accessed on: 14 Dec. 2020.

PIRES, B. Divulgação falha e parcial de dados entra em choque com discurso de transparência no Governo Bolsonaro. El País Brasil, São Paulo, 1 Feb. 2020a. Available at: https: / /brasil.elpais.com/brasil/2020-0201/divulgacao-falha-e-parcial-de-dados-entra-em-choque-com-discurso-de-transparencia-no-governo-bols onaro.html. Accessed on: 16 Sep. 2020.

PIRES, B. Aras prorroga Lava Jato de Curitiba por mais quatro meses. O Estado de S. Paulo, Brasília, 9 Sep. 2020b. Available at: https: / / politica.estadao.com.br/blogs/fausto-macedo/aras-prorroga-lava-jato-decuritiba-por-mais-quatro-meses. Accessed on: 2 Nov. 2020. 
PIRES, B. Ministro de Bolsonaro faz acordo com a PGR, admite caixa 2 e aceita pagar multa para se livrar de processo. O Estado de S. Paulo, Brasília, 3 Aug. 2020c. https: / / politica.estadao.com.br/blogs/ fausto-macedo/ministro-de-bolsonaro-admite-caixa-2-e-aceita-pagar-multa-para-se-livrar-de-processo/. Accessed on: 3 Nov. 2020.

PIRES, B. Em conflito com Lava Jato, PGR diz que modelo de forças-tarefa é incompatível. O Estado de S. Paulo, Brasília, 1 Jul. 2020d. Available at: https:/ / politica.estadao.com.br/blogs/fausto-macedo/ em-conflito-com-lava-jato-pgr-diz-que-modelo-de-forcas-tarefa-e-incompativel. Accessed on: 2 Oct. 2020.

PIRES, B. "Coaf foi oferecido por Guedes e Moro, de bom grado, aceitou." O Estado de S. Paulo, Brasília, 1 May 2019. Available at: https: / / politica.estadao.com.br/blogs/fausto-macedo/coaf-foi-oferecidopor-guedes-e-moro-de-bom-grado-aceitou. Accessed on: 2 Aug. 2020.

PIRES, B.; CAMPOREZ, P. Exclusivo: Planalto libera R \$ 3 bi em obras a 285 parlamentares em meio à eleição no Congresso. O Estado de S. Paulo, Brasília, 28 Jan. 2021a. Available at: https: / / politica.estadao. com.br/noticias / geral,planalto-libera-r-3-bi-em-obras-a-285-parlamentares-em-meio-a-disputa-nocongresso, 70003597254. Accessed on: 7 Feb. 2021.

PIRES, B.; CAMPOREZ, P. Planalto repassou milhões de verba extra a caciques do Congresso. O Estado de S. Paulo, Brasília, 29 Jan. 2021b. Available at: https: / / politica.estadao.com.br/noticias/geral, governo-repassou-milhoes-de-verba-extra-para-caciques-do-congresso, 70003598783. Accessed on: 7 Feb. 2021.

PIRES, B.; FERNANDES, A.; MONTEIRO, T. Intervenção de Bolsonaro gera crise na PF e na Receita. O Estado de S. Paulo, Brasília, 17 Aug. 2019. Available at: https://politica.estadao.com.br/noticias/ geral,intervencao-de-bolsonarogera-crise-na-pf-e-na-receita,70002971126. Accessed on: 8 Jul. 2020.

PIRES, B.; TURTELLI, C. Líder do governo Bolsonaro se alia a petista para abrandar lei de improbidade. $O$ Estado de S. Paulo, Brasília, 23 Sep. 2020. Available at: https: / / politica.estadao.com.br/noticias/geral,liderdo-governo-bolsonaro-se-alia-a-petista-para-abrandar-lei-de-improbidade, 70003449813. Accessed on: 7 Dec. 2020.

PODER360. Centrão ganhou ao menos 17 cargos depois de aproximação com Bolsonaro. Poder360, Brasília, 19 June 2020. Available at: https://www.poder360.com.br/infograficos/centrao-ganhouao-menos-17-cargos-depois-de-aproximacao-com-bolsonaro. Accessed on: 10 Oct. 2020.

PONTES, J.; ANSELMO, M. Crime.gov: Quando Corrupção e Governo se Misturam. São Paulo: Objetiva, 2019. 
PORTINARI, N. Planalto admite retirar Coaf de Moro, diz relator. O Globo, Brasília, 6 May 2019. Available at: https://oglobo.globo.com/brasil/planalto-admite-retirar-coaf-de-moro-diz-relator-23643679. Accessed on: 10 Apr. 2020.

POWELL, G. B. J. The Quality of Democracy: The Chain of Responsiveness. Journal of Democracy, v. 15, n. 4, p. $91-105,2004$.

POWER, T. J.; TAYLOR, M. M. Introduction: Accountability Institutions and Political Corruption in Brazil. In: POWER, T. J.; TAYLOR, M. M. (ed.). Corruption and Democracy in Brazil: The Struggle for Accountability. Notre Dame: University of Notre Dame Press, 2011.

PRAÇA, S. Guerra à corrupção: Lições da Lava Jato. São Paulo: Évora, 2017.

PRAÇA, S. Corrupção e reforma institucional no Brasil, 1988-2008. Opinião Pública, v. 17, n. 1, p. 137-162, 2011.

PRAÇA, S.;TAYLOR, M. M. Inching Toward Accountability: The Evolution of Brazil's Anticorruption Institutions, 1985-2010. Latin American Politics and Society, v. 56, n. 2, p. 27-48, 2014. Available at: https://doi.org/10.1111/j.1548-2456.2014.00230.x. Accessed on: 10 Apr. 2020.

PRADO, M. M.; CORNELIUS, E. Institutional Multiplicity and the Fight against Corruption: A Research Agenda for the Brazilian Accountability Network. Revista Direito GV, São Paulo, v. 16, n. 3, e1974, 2020.

PRAZERES, L. Governo nega acesso a estudos que basearam orientação para usar cloroquina em pacientes leves da Covid-19. O Globo, Brasília, 19 June 2020. Available at: https://oglobo.globo.com/sociedade/ governo-nega-acesso-estudos-que-basearam-orientacao-para-usar-cloroquina-em-pacientes-leves-da-covid19-1-24488755. Accessed on: 10 Oct. 2020.

RAGSDAlE, L. The Politics of Presidential Speechmaking, 1949-1980. The American Political Science Review, v. 78, n. 4, p. 971-984, 1984. Available at: https://doi.org/10.2307/1955802. Accessed on: 10 Apr. 2020.

RAMOS, M. et al. Escândalo da Petrobras: Partidos e empreiteiras no juízo final. Época, Rio de Janeiro, 14 Nov. 2014. Available at: https: / / epoca.globo.com/tempo/noticia/2014/11/bescandalo-da-petrobrasbpartidos-e-empreiteiras-no-juizo-final.html. Accessed on: 10 Apr. 2020.

RAUCH, J. E.; EVANS, P. B. Bureaucratic Structure and Bureaucratic Performance in Less Developed Countries. Journal of Public Economics, v. 75, n. 1, p. 49-71, 2000. Available at: https://doi.org/ 10.1016/S0047-2727(99)00044-4. Accessed on: 10 Apr. 2020. 
RESENDE, T.; CHAIB, J.; CARNEIRO, M. Preferido de Bolsonaro, Arthur Lira lança candidatura à presidência da Câmara. Folha de S.Paulo, Brasília, 9 Dec. 2020. Available at: https://www1.folha. uol.com.br/poder/2020/12/candidato-de-bolsonaro-arthur-lira-lanca-candidatura-a-presidencia-dacamara.shtml. Accessed on: 8 Feb. 2021.

REUTERS. Brazil's top court approves investigation into Bolsonaro chief of staff. Reuters, Brasília, 4 Dec. 2018. Available at: https:/ /www.reuters.com/article/brazil-politics-lorenzoni-idUSL8N1Y94OM. Accessed on: 17 Apr. 2021.

REUTERS. Brazil prosecutors file charges against tourism minister. Reuters, Brasília, 4 Oct. 2019. Available at: https:/ / www.reuters.com/article/us-brazil-politics-fraud/brazil-prosecutors-file-chargesagainst-tourism-minister-idUSKBN1WJ2AS. Accessed on: 17 Apr. 2020.

RICHTER, A. Top Court Opens Inquiry into Moro’s Allegations against Bolsonaro. Agência Brasil, Brasília, 28 Apr. 2020. Available at: https://agenciabrasil.ebc.com.br/en/justica/noticia/2020-04/top-courtopens-inquiry-moros-allegations-against-bolsonaro. Accessed on: 30 May 2020.

RICHTER, A.; PONTES, F. Fachin diz que foro privilegiado é "incompatível com o princípio republicano”. Agência Brasil, Brasília, 17 Feb. 2017. Available at: https://agenciabrasil.ebc.com. br/politica/noticia/2017-02/fachin-diz-que-foro-privilegiado-e-incompativel-com-o-principio-republicano. Accessed on: 17 Apr. 2020.

ROCHA, M. Aras afirma que Lava Jato em Curitiba é “caixa de segredos”. Folha de S.Paulo, Brasília, 28 July 2020. Available at: https: / / www1.folha.uol.com.br/poder/2020/07/aras-afirma-que-lava-jatoem-curitiba-e-caixa-de-segredos.shtml. Accessed on: 17 Oct. 2020.

ROCHA DE BARROS, C. How Lava Jato Died - and What Comes Next. Americas Quarterly, Rio de Janeiro, 15 Oct. 2020. Available at: https://www.americasquarterly.org/article/how-lava-jato-died-and-whatcomes-next/. Accessed on: 17 Oct. 2020.

RODRIGUES, F. Conheça a história da compra de votos a favor da emenda da reeleição. Blog do Fernando Rodrigues, Brasília, 16 June 2014. Available at: https: / / fernandorodrigues.blogosfera.uol.com.br / 2014/06/16/ conheca-a-historia-da-compra-de-votos-a-favor-da-emenda-da-reeleicao/. Accessed on: 10 Apr. 2020.

RODRIGUES, F.; LOBATO, E. FHC tomou partido de consórcio no leilão das teles, revelam fitas. Folha de S.Paulo, São Paulo, 25 May 1999. Available at: https://www1 folha.uol.com.br/fsp/brasil/especial/ sp7.htm. Accessed on: 10 Apr. 2020. 
RODRIGUES, K. F. The politics of Brazil's access to information policies: history and coalitions. Revista de Administração Pública, v. 54, n. 1, p. 142-161, 2020.

ROSA, V. Bolsonaro oferece cargos a partidos em troca de sustentação no Congresso. O Estado de S. Paulo, Brasília, 18 Apr. 2020. Available at: https://politica.estadao.com.br/noticias/geral,bolsonaro-oferececargos-a-partidos-em-troca-de-sustentacao-no-congresso,70003275787. Accessed on: 10 Feb. 2021.

ROSE-ACKERMAN, S.; PIMENTA, R. M. Corruption in Brazil: Beyond Criminal Law. In: LAGUNES, P.; SVEJNAR, J. (ed.). Corruption and the Lava Jato Scandal in Latin America. New York: Routledge, 2020.

ROUSSEFF, D. et al. Mensagem Presidencial no 316. Brasília, DF: 2009. Available at: https://www. camara.leg.br/proposicoesWeb/prop_mostrarintegra?codteor $=656533 \&$ filename $=$ Tramitacao-MSC + 316/2009+\%3D\%3E+PL+5228/2009. Accessed on: 17 Apr. 2021.

SACONI, J. P. "Rachadinha”: entenda o caso de Flávio Bolsonaro após decisões do STJ. O Globo, Rio de Janeiro, 17 Mar. 2021. Available at: https://oglobo.globo.com/brasil/rachadinha-entenda-caso-deflavio-bolsonaro-apos-decisoes-do-stj-24928221. Accessed on: 17 Apr. 2021.

SADEK, M. T. A. Combate à corrupção: novos tempos. Revista da CGU, v. 11, n. 20, p. 1276-1283, 2019.

SAKAMOTO, L. Bolsonaro não se importar com "laranjal" de ex-ministro resume seu governo. UOL, São Paulo, 9 Dec. 2020. Available at: https: / / noticias.uol.com.br/colunas/leonardo-sakamoto/2020 / 12/09/bolsonaro-nao-se-abalar-com-laranjal-de-ex-ministro-explica-o-seu-governo.htm. Accessed on: 10 Apr. 2021.

SANCHES, M. OCDE adota medida inédita contra o Brasil após sinais de retrocesso no combate à corrupção no país. BBC, 15 Mar. 2021, sec. Brasil. Available at: https://www.bbc.com/portuguese/ brasil-56406033. Accessed on: 17 Apr. 2021.

SARDINHA, E. Centrão age nos bastidores para impedir votação de prisão em $2^{a}$ instância. Congresso em Foco, Brasília, 29 Sep. 2020. Available at: https: / / congressoemfoco.uol.com.br/legislativo/centraoage-nos-bastidores-para-impedir-votacao-de-prisao-em-2a-instancia/. Accessed on: 10 Apr. 2020.

SARTORI, C. Tribunal de Justiça do Rio dá foro privilegiado a Flávio Bolsonaro e tira inquérito das rachadinhas da primeira instância. O Estado de S. Paulo, Rio de Janeiro, 25 June 2020. Available at: https: / / politica.estadao.com.br/blogs/fausto-macedo/justica-do-rio-aceita-pedido-de-flavio-bolsonaropara-ser-julgado-na-segunda-instancia/. Accessed on: 10 Apr. 2021. 
SCHNEIDER, B. R. Brazil under Collor: Anatomy of a Crisis. World Policy Journal, v. 8, n. 2, p. 321-347, 1991.

SCHREIBER, M. STJ rejeita recurso de Flávio Bolsonaro que tentava anular investigação da "rachadinha". BBC News Brasil, Brasília, 16 Mar. 2021. Available at: https:/ / www.bbc.com/portuguese/brasil-56423776. Accessed on: 17 Apr. 2021.

SENRA, R. Não é só Flávio Bolsonaro: MP investiga em sigilo dezenas de deputados após rachadinhas no RJ. BBC News Brasil, London, 25 June 2020. Available at: https:/ / www.bbc.com/portuguese/brasil53172048. Accessed on: 10 Apr. 2021.

SERAPIÃO, F. Coaf relata conta de ex-assessor de Flávio Bolsonaro. O Estado de S. Paulo, Brasília, 6 Dec. 2018. Available at: https:/ / politica.estadao.com.br/blogs/fausto-macedo/coaf-relata-conta-de-ex-assessorde-flavio-bolsonaro. Accessed on: 10 Apr. 2020.

SHALDERS, A. 4 perguntas para entender a reviravolta no caso das candidatas 'laranjas' do PSL de Bolsonaro. BBC News Brasil, Brasília, 8 Oct. 2019. Available at: https://www.bbc.com/portuguese/brasil-49980067. Accessed on: 10 Apr. 2020.

SIMÕES, M. Brazil's Polarizing New President, Jair Bolsonaro, in His Own Words. The New York Times, New York, 8 Oct. 2018. Available at: https: / /www.nytimes.com/2018/10/28/world/americas/brazilpresident-jair-bolsonaro-quotes.html. Accessed on: 10 Apr. 2020.

SIMON, R. Bolsonaro's Siege Against Law Enforcement Agencies. Americas Quarterly, 12 Sep. 2019. Available at: https: / / www.americasquarterly.org/article/bolsonaros-siege-against-law-enforcement-agencies. Accessed on: 10 Oct. 2020.

SIMON, R.; SWEIGART, E. The Risky Politics of Anti-Money Laundering. Americas Quarterly, 27 Apr. 2020. Available at: https://www.americasquarterly.org/article/the-risky-politics-of-anti-moneylaundering. Accessed on: 10 Oct. 2020.

SOARES, P. R. Auditor citado pela defesa de Flávio Bolsonaro é exonerado da chefia da Corregedoria da Receita Federal no Rio. Jornal Hoje, Brasília, 5 Dec. 2020. Available at: https://g1.globo.com/rj/rio-dejaneiro/noticia/2020/12/05/auditor-citado-pela-defesa-de-flavio-bolsonaro-e-exonerado-da-chefia-da-cor regedoria-da-receita-federal-no-rio.ghtm. Accessed on: 10 Apr. 2021.

SOARES, J.; PIRES, B. Saiba quem é Ricardo Barros, ex-ministro de Temer e novo líder de Bolsonaro na Câmara. O Estado de S. Paulo, Brasília, 12 Aug. 2020. Available at: https: / / politica.estadao.com.br/noticias/ geral,saiba-quem-e-ricardo-barros-ex-ministro-de-temer-e-novo-lider-de-bolsonaro-na-camara, 70003397329. Accessed on: 10 Oct. 2020. 
SOUZA, R. Itamaraty trata como "sigilosos" documentos sobre ideologia de gênero. Correio Braziliense, Brasília, 10 Sep. 2019. Available at: https://www.correiobraziliense.com.br/app/noticia/brasil/2019/ 09/10/interna-brasil,781601/itamaraty-trata-como-sigilosos-documentos-sobre-ideologia-de-genero. shtml. Accessed on: 10 Apr. 2020.

STOKES, S. C. Mandates and Democracy: Neoliberalism by Surprise in Latin America. New York: Cambridge University Press, 2001.

TALENTO, A. Cotado para PGR, Aras afirma que Lava-Jato tem “desvios a serem corrigidos". O Globo, Brasília, 12 Aug. 2019. Available at: https:/ / oglobo.globo.com/brasil/cotado-para-pgr-aras-afirmaque-lava-jato-tem-desvios-serem-corrigidos-23872644. Accessed on: 10 Apr. 2020.

TALENTO, A. Onyx faz acordo com PGR, admite caixa dois e paga R \$ 189 mil para encerrar processo. O Globo, Brasília, 3 Aug. 2020. Available at: https: / / oglobo.globo.com/brasil/onyx-faz-acordo-com-pgradmite-caixa-dois-paga-189-mil-para-encerrar-processo-24564497. Accessed on: 10 Oct. 2020.

TAVARES, A. C. Caso Jorgina de Freitas trouxe à luz fraude bilionária na Previdência. O Globo, Rio de Janeiro, 9 Dec. 2015. Available at: https: / / acervo.oglobo.globo.com/em-destaque/caso-jorgina-de-freitastrouxe-luz-fraude-bilionaria-na-previdencia-18255400. Accessed on: 10 Apr. 2020.

TAYLOR, M. M.; BURANELLI, V. C. Ending up in Pizza: Accountability as a Problem of Institutional Arrangement in Brazil. Latin American Politics and Society, v. 49, n. 1, p. 59-87, 2007. Available at: https:// doi.org/10.1111/j.1548-2456.2007.tb00374.x. Accessed on: 10 Apr. 2020.

TEIXEIRA, M. 2021. Em decisão incomum, STF rejeita denúncia que havia aceitado contra Lira e cúpula do PP em 2019. Folha de S.Paulo, Brasília, 2 Mar. 2021. Available at: https: / /www1.folha.uol. com.br/poder/2021/03/em-decisao-incomum-stf-rejeita-denuncia-que-havia-aceitado-contra-lirae-cupula-do-pp-em-2019.shtml. Accessed on: 17 Apr. 2021.

TEIXEIRA, M. STF forma maioria para manter réu líder do Centrão acusado de corrupção passiva. Folha de S. Paulo, Brasília, 24 Nov. 2020. Available at: https://www1 folha.uol.com.br/poder/2020/11/stfforma-maioria-para-manter-lider-do-centrao-reu-acusado-de-corrupcao-passiva.shtml. Accessed on: 10 Oct. 2020.

TI. Brazil's Carwash Task Force Wins Transparency International Anti-Corruption Award. Transparency International, Panama City, 3 Dec. 2016. Available at: https://www.transparency.org/en/press/ transparency-international-supports-the-carwash-task-force-in-their-fight-f. Accessed on: 10 Oct. 2020. 
TORGLER, B.; VALEV, N. T. Gender and Public Attitudes toward Corruption and Tax Evasion. Contemporary Economic Policy, v. 28, n. 4, p. 554-68, 2010.

TURTElli, C.; WeTERMAN, D.; BORGES, A. O que Bolsonaro quer do Congresso: da venda da Eletrobrás ao acesso mais fácil a armas. O Estado de S. Paulo, Brasília, 3 Feb. 2021. Available at: https:// politica.estadao.com.br/noticias/geral, prioridades-de-bolsonaro-no-congresso-vao-de-privatizacao-daeletrobras-a-flexibilizacao-de-armas,70003603951. Accessed on: 10 Apr. 2021.

UOL. Bolsonaro diz que missão é livrar país da corrupção e submissão ideológica. $U O L$, Brasília, 1 Jan. 2019. Available at: https://noticias.uol.com.br/politica/ultimas-noticias/2019/01/01/bolsonaroprimeiro-discurso-presidente-congresso.htm. Accessed on: 10 Apr. 2020.

UOL. Pelo menos 11 escândalos de corrupção sacudiram país desde mensalão; relembre. UOL, Brasília, 5 June 2015. Available at: https: / / noticias.uol.com.br/politica/ultimas-noticias/2015/06/05/pelo-menos11 -escandalos-de-corrupcao-sacudiram-pais-desde-mensalao-relembre.htm. Accessed on: 10 Apr. 2020.

VALENTE, G.; IGLESIAS, S. Alvo da Lava-Jato, Luiz Otávio foi afastado do Ministério dos Transportes. O Globo, Rio de Janeiro, 16 Feb. 2017. Available at: https://oglobo.globo.com/brasil/alvo-da-lavajato-luiz-otavio-foi-afastado-do-ministerio-dos-transportes-20935130. Accessed on: 10 Apr. 2020.

VASCONCELOS, F. Justiça anula punição a réus do escândalo Banestado. Folha de S.Paulo, São Paulo, 23 Apr. 2013. Available at: https://m.folha.uol.com.br/poder/2013/04/1267100-justica-anulapunicao-a-reus-do-escandalo-do-banestado.shtml. Accessed on: 10 Apr. 2020.

VEJA. IBGE vai cortar 25\% do orçamento e revisar metodologia do Censo. Veja, Rio de Janeiro, 9 Apr. 2019. Available at: https://veja.abril.com.br/economia/ibge-vai-cortar-25-do-orcamento-e-revisarmetodologia-do-censo/. Accessed on: 10 Apr. 2020.

VENAGLIA, G.; LIMA, K. Augusto Aras: “É hora de corrigir rumos para que o lavajatismo não perdure”. CNN Brasil, São Paulo, 28 July 2020. Available at: https: / /www.cnnbrasil.com.br/politica/2020/07/28 / augusto-aras-e-hora-de-corrigir-rumos-para-que-lavajatismo-nao-perdure. Accessed on: 10 Oct. 2020.

VENCESLAU, P.; LINDNER, J. Discurso de Bolsonaro "incentiva desobediência" e é "escalada antidemocrática”, dizem políticos. O Estado de S. Paulo, São Paulo, 19 Apr. 2020. Available at: https: / / politica. estadao.com.br/noticias/geral,discurso-de-bolsonaro-incentiva-desobediencia-e-e-escalada-antidemocraticadizem-politicos, 70003276430. Accessed on: 17 Apr. 2021.

WAISBORD, S. Watchdog Journalism in South America: News, Accountability, and Democracy. New York: Columbia University Press, 2000. 
WATTS, J. Brazil Erupts in Protest: More Than a Million on the Streets. The Guardian, Rio de Janeiro, 21 June 2013. Available at: http://www.theguardian.com/world/2013/jun/21/brazil-police-crowdsrio-protest. Accessed on: 10 Apr. 2020.

WEYLAND, K. The Rise and Fall of President Collor and Its Impact on Brazilian Democracy. Journal of International Studies andWorld Affairs, v. 35, n. 1, p. 1-37, 1993.

WILSON CENTER. Jair Bolsonaro - Candidate Bio. Washington, DC: Brazil Institute, 2018. Available at: https: / /www.wilsoncenter.org/article/jair-bolsonaro-candidate-bio. Accessed on: 10 Apr. 2020.

XP/IPESPE. Pesquisa com a populacao. 28-30 Apr. 2020. Available at: https://conteudos.xpi.com. $\mathrm{br} /$ politica/pesquisa-xp-abril-2020-avaliacao-positiva-de-bolsonaro-cai-4-pontos-2/. Accessed on: 10 Apr. 2020.

\section{HOW TO QUOTE THIS ARTICLE:}

LAGUNES, Paul et al. President Bolsonaro's Promises and Actions on Corruption Control. Revista Direito GV, v. 17, n. 2, maio/ago. 2021, e2121. https://doi.org/10.1590/23176172202121

\section{Paul Lagunes}

He is currently serving as a Postdoctoral Fellow With the Georgetown McCourt School of Public Policy and was PREVIOUSLY AN ASSOCIATE PROFESSOR AT COLUMBIA UNIVERSITY'S School of International and Public Affairs. His Research EXAMINES THE ISSUE OF CORRUPTION, ESPECIALLY AS IT AFFECTS GOVERNMENTS IN THE AMERICAS. HIS MOST RECENT BOOK IS THE EYE and the WhiP: CORRUPtion CONTROL IN THE AMERICAS lOXFORD UNIVERSITY PRESS).

paul.lagunes@agmail.com

Gregory Michener

Professor at Fundação Getulio Vargas (FGV). His Research FOCUSES ON TRANSPARENCY AND RELATED TOPICS. MICHENER HELPED LEAD THE BRAZILIAN CAMPAIGN FOR A FREEDOM OF INFORMATION LAW.

At the FGV, he founded and leads the Program for Public TRANSPARENCY (PTP-FGV) AND THE TRANSPARENCY EVALUATION NETWORK. HIS WORKS HAVE BEEN PUBLISHED IN MULTIPLE OUTLETS, INCLUDING: GOVERNANCE, WORLD DEVELOPMENT, THE JOURNAL OF Democracy, and Public Administration. gregory.michenerafgv.br

Fernanda Odilla

Postdoctoral Researcher at the Department of Political and SOCIAL SCIENCES, University OF BOLOGNA, AND AN AFFILIATE 
PRESIDENT BOLSONARO'S PROMISES AND ACTIONS ON CORRUPTION CONTROL : $5 \mathbf{5}$

Researcher at the King's Brazil Institute, King's College London. She holds a PhD in Social Science and Public Policy and a Masters in Criminology from King's College London.

fernand.vasconcellosaunibo.it

Breno Pires

INVESTIGATIVE JOURNALIST WORKING AS A REPORTER AT O ESTADO DE S. PaUlo. He WAS AWARded the InStituto Ling FELLOWSHIP to STUdY AT COLUMBIA UNIVERSITY'S SCHOOL OF INTERNATIONAL AND Public Affairs for the 2020 Spring Term. Before that he WON the Petrobras Journalism AWARd IN 2018 FOR unCovering A CRITICAL LIST OF LEGISLATORS AND MINISTERS TARGETED FOR BRIBES BY ODEBRECHT EXECUTIVES IN THE CONTEXT OF LAVA JATO.

brenolemospires@agmail.com 